\title{
SYSTEMATIC LITERATURE REVIEW ON BLOCKCHAIN ADOPTION IN BANKING
}

\author{
DOI: 10.17261/Pressacademia.2021.1458 \\ JEFA- V.8-ISS.3-2021(2)-p.126-146
}

\section{Arun Khatri ${ }^{1}$, Anjali Kaushik ${ }^{2}$}

${ }^{1}$ Management Development Institute Gurgaon, Department of Information Management, Gurugram, India. efpm19arun_k@mdi.ac.in, ORCID: 0000-0002-5895-7951

${ }^{2}$ Management Development Institute Gurgaon, Department of Information Management, Gurugram, India. anjalikaushik@mdi.ac.in, ORCID: 0000-0002-7987-4602

\begin{tabular}{l}
\hline Date Received: June 6, $2021 \quad$ Date Accepted: September 2, 2021 \\
\hline To cite this document \\
Khatri, A., Kaushik, A., (2021). Systematic literature review on blockchain adoption in banking. Journal of Economics, Finance and Accounting \\
(JEFA), 8(3), 126-146. \\
Permanent link to this document: $\underline{\text { http://doi.org/10.17261/Pressacademia.2021.1458 }}$ \\
Copyright: Published by PressAcademia and limited licensed re-use rights only.
\end{tabular}

\section{ABSTRACT}

Purpose- Blockchain has emerged as high impact disruptive technology and surpassed most of the aggressive predictions in banking and finance domain. The changing landscape in digital banking has forced the entire banking sector to look at blockchain technology as future of transactions. Blockchain is disrupting the banking industry and contributing to the increased efficiency and speed in banking. However, there exists a gap in research and development into block-chained processes in banking from an academic perspective, and this paper ia an attempt to put together the research work done in the field of blockchain adoption in banking.

Methodology- This paper's literature review process follows common and established guidelines (Levy and Ellis, 2006; Okoli, 2015; von Brocke et al., 2009; Webster and Watson, 2002) and is summarized thoroughly. We considered the IS literature in both the blockchain and the banking context. In the first step, we conduct a separate review on both streams of literature to derive a general understanding of their current state of development. In the second step, we then conflate the relevant literature and discuss it within a joint analytical framework. In doing so, we identify paths for future research and discuss the potential of blockchain technology for banking and finance sector.

Findings- In this paper we discuss the impact that blockchain will have on banking in future and show the increasing importance of distributed ledger based transactions for the banking industry. Finally, this paper brings together the research work published in several reputed databases, in hope of motivating more active engagement by academics, researchers and bankers alike. A comprehensive review of the blockchain adoption in banking to date and across the geographic areas is presented as a result of comprehensive review of literature.

Conclusion- The collaboration of blockchain and banking is not very old, comparatively novice and we have tried to include all the significant studies till date across various databases of research.

Keywords: Blockchain, banking, fintech, distributed ledger technology, Blockchain technology adoption. JEL Codes: M10, M15, O32, 033.

\section{INTRODUCTION}

The blockchain is one of the world's leading and disruptive technology for digital assets. We are using new technology to build a better financial system. The term "Blockchain Technology" typically refers to the clear, trusted, the in public accessible ledger that allows us to securely transfer the possession of unit's important exploitation public key encryption and proof of work methods. The technology uses suburbanized agreement to keep up the network, which means it is not centrally controlled by a bank, corporation or government.

The financial sector has become part of our daily life interaction the lure of blockchain was its method of verifying and tracking transactions. Instead of a trustworthy third party or a financial organization, it depends on agreement among a peer-to-peer network of computers supported complicated algorithms. Blocks of time-stamp transactions are decentralized on all systems. Blockchain is currently a concept that has received significant attention in financial technology (FinTech). It combines several computer technologies, including distributed data storage, point-to-point transmission, consensus mechanisms, and encryption 
algorithms. It has also been identified as a disruptive innovation of the Internet era. However, as blockchain is a major breakthrough in data storage and information transmission, it might fundamentally transform the existing operating models of finance and economy, which might lead to a new round of technological innovations and industrial transformation within the FinTech industry (Mu Qi-Guo 2016).

Blockchains are decentralized and permission less, which can lead to major disruptions in the financial sector, especially in payment clearing. Since 2015, a number of major international financial institutions have begun to formulate plans for the blockchain sector. Goldman Sachs, J.P. Morgan, UBS, and other banking giants have all established their own blockchain laboratories, working in close collaboration with blockchain platforms, and published a series of studies on this topic. Goldman Sachs even filed a patent for transaction settlement based on blockchain technology. Additionally, various national stock exchanges, such as the Nasdaq Stock Market and the New York Stock Exchange have also conducted in-depth research on blockchain technology. On December 30, 2015, Nasdaq announced that it had completed its first securities transaction using the blockchain transaction platform Linq. Furthermore, the US Depository Trust \& Clearing Corporation, Visa, the Society for Worldwide Interbank Financial Telecommunication, etc. have also expanded their plans in the blockchain technology sector.

The paper starts with the introduction to the blockchain technology and its potential impact on financial institutions. The second phase of the paper describes the methodology for conducting the systematic literature review including the research context and research area along-with the review process. The criteria for inclusion or exclusion of research work is framed and followed religiously during the process. The databases and qualitative synthesis of the review is selected and followed in well-defined scientific way. The systematic literature review is carefully presented in tabular form, selecting twenty-two papers, meeting our criteria for inclusion. Path for future research is discussed followed by conclusion.

\section{RESEARCH METHODOLOGY}

The methodology used for the selection and preparation of this paper is presented in Figure 1. The SLR blueprint is broadly classified in to: Research Context and ii) Research Area

\section{Figure 1: Systematic Literature Review Map}

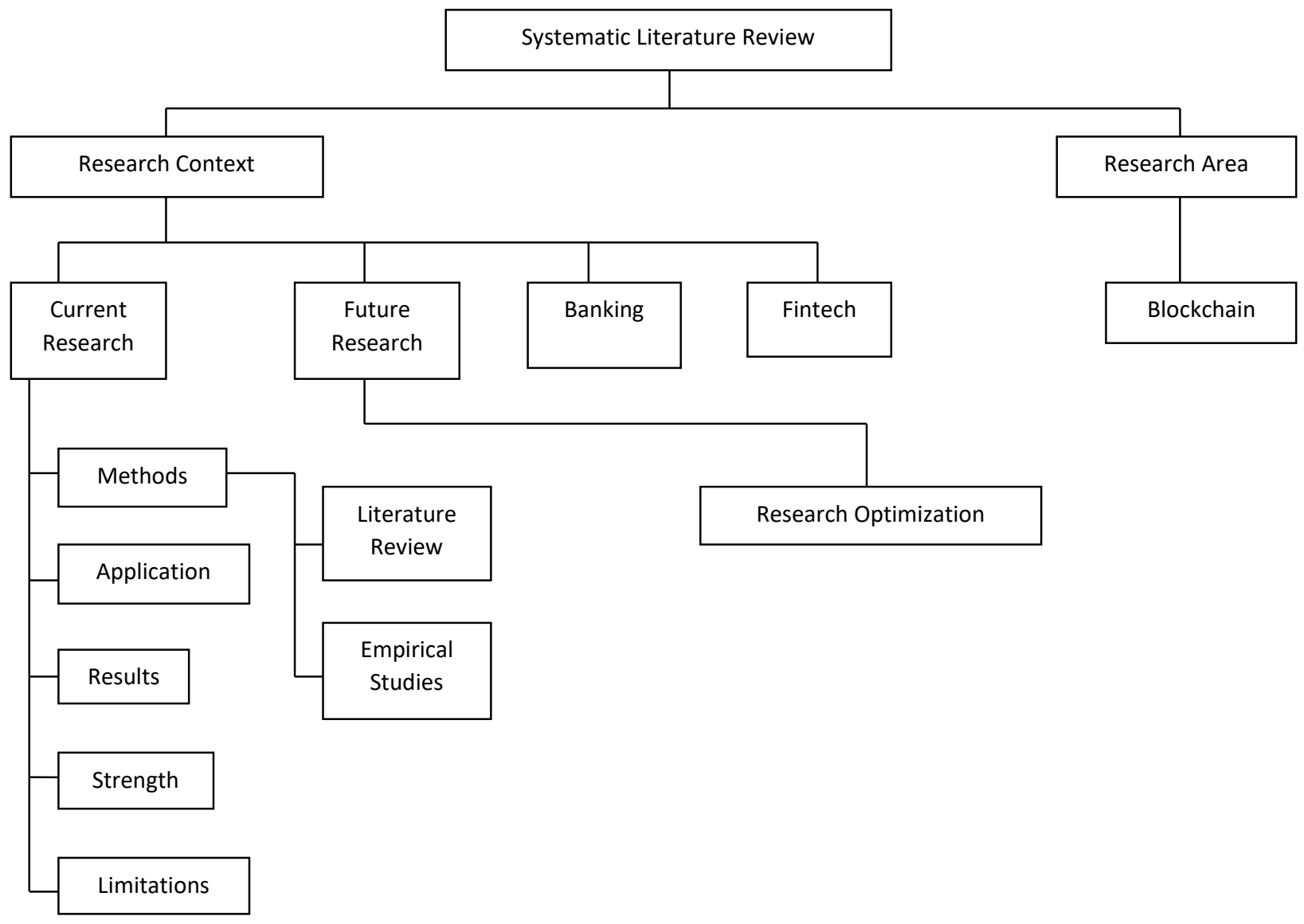


The research context covers first, current research by providing information by providing information in terms of methods, application, results, strength, and limitations using different research articles. Two types of research were examined, namely, literature reviews and empirical studies. The selected databases are EBSCO, Emerald, Elsevier, ProQuest, Scopus and Google Scholar digital databases with linear and cross searches. Secondly, it covers the future research and directions highlighting the direction of the research. The research area of this study is targeted to banking and fintech industry.

An SLR collects empirical data using a formal protocol [ ] and is typically the collection of research studies in a variety of fields [ ]. The current study conducts an SLR using the guidelines outlined by [ ]. The SLR given in this study presents the reader with a broad view of knowledge on the previous underlying studies included in this research. This research is conducted in three different stages:
a. Planning the review
b. Conducting the review
c. Reporting the review

Each of the above stages is further conducted through sub stages presented in Table 2.

\section{Figure 2: Systematic Literature Review Process}

\begin{tabular}{|c|c|}
\hline Planning the review & $\begin{array}{l}\text { 1. Specification of Research Questions } \\
\text { 2. Specification of inclusion and exclusion criteria } \\
\text { 3. Specification of digital database } \\
\text { 4. Development of review protocol } \\
\text { 5. Evaluation of review protocol }\end{array}$ \\
\hline Conducting the review & $\begin{array}{l}\text { 1. Identification of search syntax } \\
\text { 2. Data synthesis }\end{array}$ \\
\hline Reporting the review & $\begin{array}{l}\text { 1. Formatting or organization of data to demonstrate the } \\
\text { findings } \\
\text { 2. Communication of findings using visualisations }\end{array}$ \\
\hline
\end{tabular}

\subsection{Planning the Review}

The objective of the research to search and collect the current research in terms of method, and results in blockchain adoption in banking and fintech sectors, and then present the results.

Inclusion Criteria: The following inclusion criteria (IC) is used to select the literatures to be included in the review.

IC 1: The keywords used are: "blockchain", "banking", "fintech", "Distributed ledger technology", "Blockchain technology adoption". The operators used as syntax are OT and AND. The AND operator signifies that both keywords must be present in the search queries and OR means that at least one keyword must be present in the query.

IC 2: Studies published before December 31, 2019

IC 3: Studies published in English

IC 4: Studies limited to document type of journal articles

IC 5: Include abstract-based studies

IC 6: Include full-text-based studies

Exclusion Area: The exclusion criteria (EC) used to filter out the literature in this SLR are;

EC 1: Eliminate duplicate studies with matching title and /or Digital Object Identifier, doi.

EC 2: Eliminate the studies based on quality evaluation 
Digital Databases: The digital databases used to collect the data for the review of papers are;

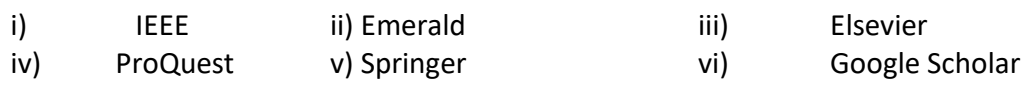

Review Protocol Development: Google Scholar was first considered to extract data from these digital databases because: i) there is an extensive amount of studies available in context with our topic that are indexed, ii) it is the leading digital literature database which includes peer reviewed papers, iii) it has extensive scientific and inter disciplinary information. EBSCO, Emerald, Elsevier, ProQuest and Scopus were also reviewed for the papers. Furthermore, additional relevant papers matching the context of this study were included on the basis of full text citation.

Review Protocol Evaluation: To support the criteria of inclusion, exclusion, and the selection of research data, it is vital to examine and evaluate the quality of studies. In fact, the purpose of the quality assessment is to make sure that the results of the study are suitable and impartial.

The various stages for data selection are shown in Figure 2 in a sequential manner. Each of the stage shown in the figure is executed with the accompanying IC, inclusion criteria and EC, exclusion criteria.

Figure 3: Data Selection Stages

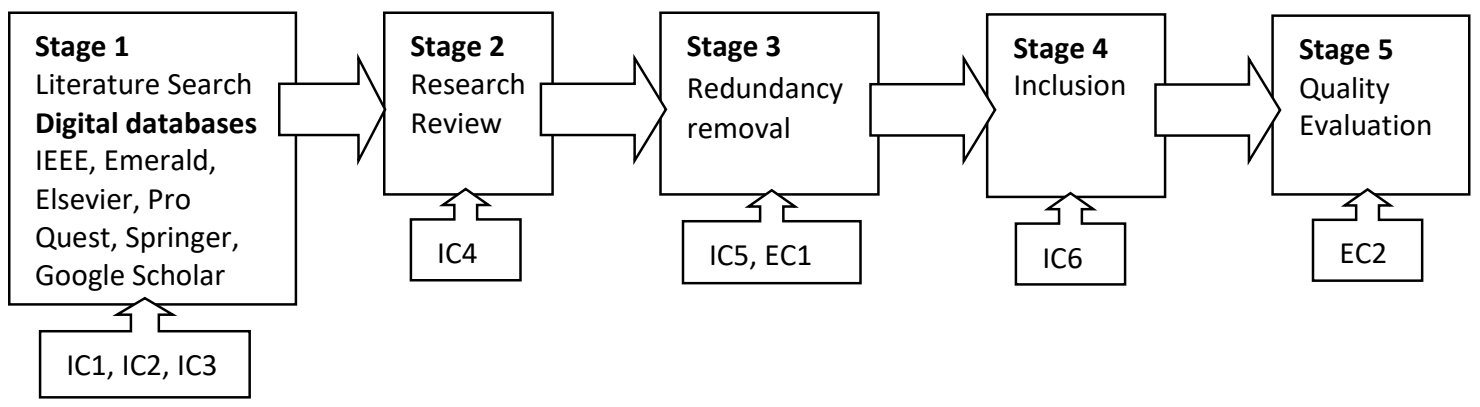

\subsection{Conducting the Review}

The search syntax used in this SLR for selecting the research papers is shown in Table1.

Table 1: Search Syntax of the Selected Research Papers

\begin{tabular}{|c|c|}
\hline Data Source & Search Syntax \\
\hline EBSCO & $\begin{array}{l}\text { (TITLE-ABS-KEY (“blockchain”) OR TITLE-ABS-KEY (“blockchain adoption” )OR TITLE-ABS-KEY (“banking” OR } \\
\text { "fintech”) AND (LIMIT-TO(LANGUAGE,"”"English”)) }\end{array}$ \\
\hline Emerald & $\begin{array}{lllllllll}\text { (“blockchain" } & \text { OR “blockchain } & \text { adoption" } & \text { OR } & \text { "banking" } & \text { OR } & \text { "fintech") } & \text { AND } & \text { (LIMIT- } \\
\text { TO(LANGUAGE,"”"English")) } & & & & & & \end{array}$ \\
\hline Elsevier & $\begin{array}{lllllllll}\text { (“blockchain" } & \text { OR “blockchain } & \text { adoption" } & \text { OR } & \text { "banking” } & \text { OR } & \text { "fintech") } & \text { AND } & \text { (LIMIT- } \\
\text { TO(LANGUAGE,"”"English")) } & & & & & & \end{array}$ \\
\hline Proquest & 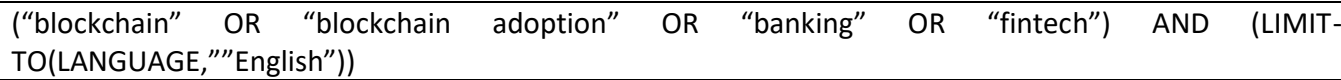 \\
\hline Google Scholar & $\begin{array}{l}\text { (TITLE-ABS-KEY (“blockchain”) OR TITLE-ABS-KEY (“blockchain adoption” )OR TITLE-ABS-KEY ("banking” OR } \\
\text { "fintech") AND (LIMIT-TO(LANGUAGE,"”English”)) }\end{array}$ \\
\hline
\end{tabular}

TITLE-ABS-KEY: The keywords are searched for in the: title, abstract and keywords of the paper.

AND: This operator means that both keywords in the searched item should be there in the conditional output of the search.

OR: This operator means that any one keywords in the searched item should be there in the conditional output of the search.

LIMIT-TO-LANGUAGE: This operator means that the search must be limited to English language only. 
Data Synthesis - To explain the methods, results, applications and limitations of the current and available research, a qualitative meta-synthesis technique is used. Figure 4 presents the output of this technique. Figure 4 shows;
I. Search strategy including linear literature search
II. Number of studies at each stage of the process
III. The summary of studies selected

Figure 4: Output of the Qualitative Synthesis Technique

\begin{tabular}{|c|c|c|c|c|}
\hline $\begin{array}{l}\text { Stage } 1 \\
\text { Literature } \\
\text { Search Digital } \\
\text { databases: } \\
\text { EBSCO, Emerald, } \\
\text { Elsevier, } \\
\text { ProQuest, } \\
\text { Scopus, Google } \\
\text { Scholar on the } \\
\text { basis of } \\
\text { keywords and } \\
\text { language: } \\
\text { English and by } \\
\text { the end of } \\
\text { December } 2019 . \\
\text { Initial Search } \\
\text { Results } \\
\text { IEEE } \\
\text { Emerald } \\
\text { Elsevier } \\
\text { Pro Quest } \\
\text { Springer } \\
\text { Google Scholar } \\
\text { Total articles: }\end{array}$ & $\begin{array}{l}\text { Stage } 2 \\
\text { Research } \\
\text { review on the } \\
\text { basis of study. } \\
\text { IEEE } \\
\text { Emerald } \\
\text { Elsevier } \\
\text { Pro Quest } \\
\text { Springer } \\
\text { Google Scholar } \\
\text { Total articles } \\
\text { included: } \\
\text { Total articles } \\
\text { excluded: }\end{array}$ & $\begin{array}{l}\text { Stage } 3 \\
\text { Redundancy } \\
\text { removal on the } \\
\text { basis of } \\
\text { abstract. } \\
\text { IEEE } \\
\text { Emerald } \\
\text { Elsevier } \\
\text { Pro Quest } \\
\text { Springer } \\
\text { Google Scholar } \\
\text { Total articles } \\
\text { included: } \\
\text { Total articles } \\
\text { excluded: }\end{array}$ & $\begin{array}{l}\text { Stage } 4 \\
\text { Inclusion of } \\
\text { studies. } \\
\text { IEEE } \\
\text { Emerald } \\
\text { Elsevier } \\
\text { Pro Quest } \\
\text { Springer } \\
\text { Google Scholar } \\
\text { Total articles } \\
\text { included: } \\
\text { Total articles } \\
\text { excluded: }\end{array}$ & $\begin{array}{l}\text { Stage } 5 \\
\text { Quality } \\
\text { Evaluation. } \\
\text { IEEE } \\
\text { Emerald } \\
\text { Elsevier } \\
\text { Pro Quest } \\
\text { Springer } \\
\text { Google Scholar } \\
\text { Total articles } \\
\text { included: } \\
\text { Total articles } \\
\text { excluded: }\end{array}$ \\
\hline
\end{tabular}

In stage 1, a total of 42 were found with the selected keywords, English language and restricted until December 2019. The proceedings of the papers selected and chosen for the study can be easily understood from the Figure 4 . In all 23 papers were found to be relevant to this study.

The list of selected papers considered for this study is presented in Table 1 andf Appendix A. 


\section{Figure 5: Distribution of Papers by First Author and by Category}

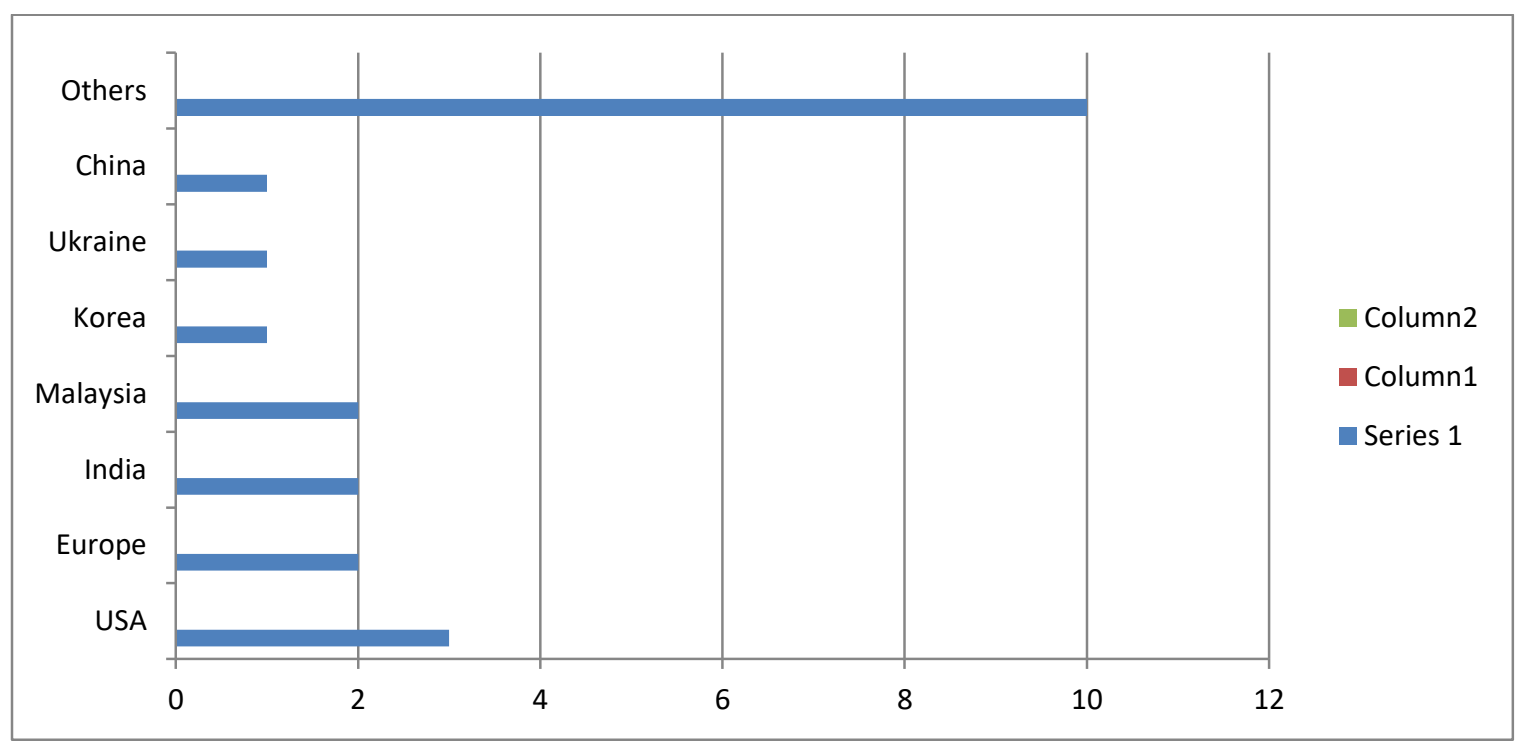

Figure 5 shows the distribution of research papers by the first authors' country and it indicates that the United States has contributed the highest number of articles among other countrie

\section{Figure 6: Distribution of Papers by Year of Publication and Digital Database}

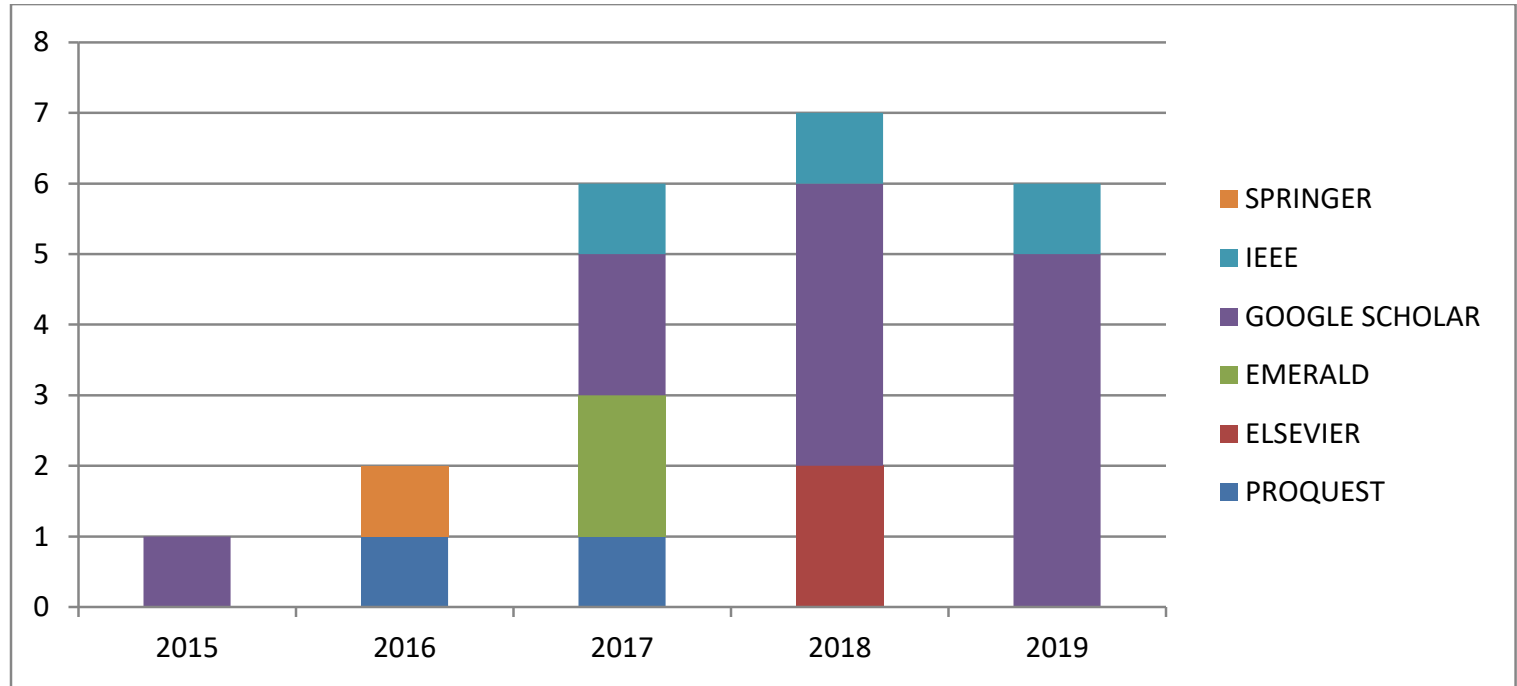

Figure 6 shows the distribution of papers by year of publication and digital databases, and it indicates that 2018 had the highest number of articles for this study.

\section{LITERATURE SURVEY}

The retrieved articles were analyzed based on title, abstract, and keywords. The two main election criteria were chosen: 1) key word based selection on Blockchain technology and its application in the banking industry. 2) the international standard published research in the most respected journals. As a result, 22 articles were considered for further review. When in doubt, the paper was selected for a full-text analysis. 
Gupta and Gupta (2018) provide an overview of Blockchain Technology with its benefits and emphasizing on the applications of the technology in the Indian Banking Sector. The paper gives the insight of various challenges and global perspective of Blockchain Technology in banking industry. One disruptive innovation which is changing the banking sector globally is Blockchain Technology (BCT). The study concludes that, blockchain will evolve as a disruptive force in transforming Indian Banking Sector by making banking transactions more secure, faster, transparent, and cost effective. The authors have used secondary data for the current study. An empirical research can be undertaken in future to present the growth of Bitcoin Technology in India with respect to other developing countries.

Guo and Liang (2016) conclude that blockchains have a technological advantage over banks as credit intermediaries, it is still too early for this technology to completely disrupt the existing financial Therefore, a "multi-center, weakly intermediated" scenario is likely to emerge. This is where banks use blockchain technology to improve their payment clearing systems and overcome certain obstacles in information communication, while also forming consortiums, thereby consolidating their position. Chinese banking and fintech markets are evolving with the implementation of new technology. Chinese Blockchain Technology and Application Development, 2016. Blockchain applications also promote the formation of "multi-center, weakly intermediated" scenarios, which will enhance the efficiency of the banking industry. The decentralization and self-governance of blockchains dilutes the concept of regulation, and has a critical impact on the existing system.

Barnes (2015) confers that banks like UBS, ING and Nasdaq, are exploring the potential of the technology, be able to overcome the challenges that remain, not least security and regulatory issues. The technology behind Bitcoin - has revolutionary potential. It could transform almost every aspect of commerce and make stand-ard internet transactions seem old fashioned. We have thought about the memory of money via a blockchain. That's an idea we would love to drill down into, but a little bit further down the road. Can we use this to replace existing technology, whether for transfers or payments or in the security space? Banks are making the choice to move to a 24/7 real-time payment service: instant payments but also instant business. Discussions of what kind of technology to use is an interesting dilemma: do you go for the brand new, not completely tested but very promising blockchain type of technology with everything in it or proven technology with databases. Rigor through TAM is required to analyze the adoption of the new technology.

Degener (2018) compares the Rabobank and fintech start-up Ripple in order to filter out implications to the business model of traditional banks integrating blockchain technology to process international payments. Ripple represents a value proposition offering a 'blockchain-as-a-service' solution, RippleNet, to which traditional banks can simply plug in. Ripple represents a value proposition offering a 'blockchain-as-a-service' solution. The current situation of the cross-border payment systems applied through the case of the Rabobank and the information technology perspective of Fiducia GAD. Further light is spot on the case of Ripple as representative of a blockchain based solution for a cross-border payment system. The findings suggest that blockchain technology is less likely to be successfully implemented by traditional banks in an isolated way. Instead, it seems more viable for banks to collaborate with fintech organizations, like Ripple, to capture value from the blockchain technology on a larger scale. The data collected is assumed to be clear, accurate, and of decent coverage for the purpose of this study. the scope of the targeted data is considered quite broad, therefore finding a decent expert to interview on the entire range of the business model is difficult.

Ittay (2017) states that the financial technology (FinTech) sector sees high potential value in cryptocurrency blockchain protocols, or distributed-ledger technology (DLT). However, the requirements and guarantees of blockchains for cryptocurrencies do not match those of FinTech-from transaction throughput to security primitives and privacy. The author explores how blockchain research beyond Bitcoin is closing these gaps and some of the challenges that remain. Blockchain systems can be roughly split into four layers. The system clients are at the top, and they observe an abstract system state, such as a balance sheet stating how much currency each account has. This abstraction is facilitated by a virtual machine layer that accepts transactions and translates them into state changes. new possibilities and challenges will continue to arise as DLT adoption increases in FinTech, the full potential of blockchain technologies will only be realized through direct and effective collaboration between the FinTech industry and the blockchain scientific and engineering community. Blockchain security relies on public verifiability of its integrity. Each node observes all blocks and transactions and can verify that the transactions are legal and the blocks are correctly formed. Nodes do not create money or replace it.

According to Hassani, Hossein, et. al., (2018), there exists a gap in research and development into blockchain-ed big data in banking from an academic perspective, and this gap is expected to have a significant negative impact on the adoption and development of blockchain technology for banking. review of the impact of blockchain in banking to date by summarizing the opportunities and challenges from a bankers' perspective. discuss the impact that big data from blockchain will have on banking data analytics in future and show the increasing importance of filtering and signal extraction for the banking industry. 
In Bates and Paul Migliore (2018) the authors explore the transformative technologies that will drive digital insertion efforts in the future, how asset managers will need to differentiate themselves in the new digital landscape and practical steps to embrace the digital frontier for organisations that are still held back by legacy technology, processes and behaviours. investment managers have been digitising information and processes, but we have only recently moved into a new era where firms are reengineering every facet of the business upon a digital foundation. The future state design options should be derived through an open dialogue with vendors about their current and future product offerings. Leveraging the resources and scale of an external provider helps asset managers mitigate risk by minimising initial investment and leveraging technologies tested by a subset of their peer group. These consider ations will become increasingly important components to a future state options analysis as the competitive landscape shifts to automation, processing of complex data and sophisticated Al toolsets. This paper considers all the innovative technologies and give reasons to either innovate or stagnate.

Umarovich and Natalia (2017) conduct the research of current trends and priorities for the blockchain technology use in order to ensure the economic security of large corporate entities. The subject of the research is a set of economic and organizational and financial relations ensuring the financial controlling effectiveness in large corporate entities, implemented with the blockchain technology application. A conceptual analysis of the current use of blockchain technology has been used to see the future road to its implementation. The application of blockchain can be further analysed in the light of significant proof. The conducted analysis of the blockchain application risks and benefits demonstrates the need in balancing risks and benefits of this technology application. In the Russian practice the named trend is supported: the most frequently the blockchain technology is used in financial markets.

Azarenkova and Shkodina (2018) focused on proposing the ways to reduce the negative impact of financial technologies on the financial system stability. The analysis of the financial technologies impact on the stability of financial system shows that the lack of institutional support for new financial technologies is the most important catalyst for the financial industry destabilization and the formation of financial bubbles in various market segments. This paper considers the application of new technology at global level. The global scenario does not allow to study in an organized and regulated manner. Country specific proofs are required.

Petrushenko and Kozarezenko (2018) identify disruptive challenges for financial institutions need to adapt. The aim of the research is to investigate the prospects of FinTech engagement into the system of international transfers processing in Ukraine. The research investigates the value and the investment flows structure as most obvious indicators of FinTech and describes types of payments relationships there. The paper considers relationships between enterprises, financial institutions and individuals, which are formed in digital payments. conducting a comparative analysis of the regular and innova- tive cross-border payment processes, developing a methodology for evaluating the impact of FinTech engagement into the system of cross-border payments in Ukraine, and investing foreign experience of FinTech start-ups participation in the international money transfers system. The paper shows that investments and profits of cross-border payment solution can vary significantly between countries, since each country has separate and diverse national payment systems. FinTech can help to proceed in this direction enhance the system and allow people to proceed more effective. There is a high potential of FinTech for cross-border payment processing in near future.

Cocco, Pinna, et. al. (2017) paper looks at the challenges and opportunities of implementing blockchain technology across banking, providing food for thought about the potentialities of this disruptive technology. defined three quantities: "economic efficiency", "operational efficiency", and "efficient service". First EE, defined as as the ratio between the value of bitcoins mined by the power consumption of $1 \mathrm{kWh}$, is characterised by a strong variability because it is influenced by the growing of the Bitcoin price.the Bitcoin popularity and the power consumption of the network. Second, we found that the OE, defined as the ratio between the value of voluntary fees and the energy cost of a transaction, is currently growing, indicating that fees are becoming more and more important to assure the sustainability of the Bitcoin system. In fact, mining operations will be remunerated only until the sum of circulating bitcoins reaches 21 million. SE, defined as the ratio between the number of transactions validated by the power consumption of $1 \mathrm{kWh}$, which describe how much electricity the network spends to number of transactions per block is limited, and the SE cannot increase.perform its main service, i.e., to wire bitcoin.

In Christopher (2019) the bridging model is applied first to traditional banking, to illustrate and analyze the enforcement mechanisms underpinning the U.S. dollar as currency and the banking system as a whole, and to demonstrate that the enforcement mechanisms (government backing and regulation) are not as robust as generally believed. The bridging model is then applied to Bitcoin, to show not only that the system requires more trust than is generally understood, but also that both currency and payment systems benefit from the involvement of trusted intermediaries in response to problems and crises. This article undertakes a critical deconstruction of Bitcoin and the blockchain, their themes of democracy and transparency, and the idea that they are trustless. The article enforcement and trust in contract formation model, which allows for a more nuanced 
understanding of the interplay between conceptualization of the role of trust in business and contracting: the bridging then proposes a new framework. The Bridging Model Applied to Traditional Banking: As an illustration of the bridging model in application, this Part applies the model to traditional banking, understood roughly here to mean the brick-andmortar U.S. banking system of the past hundred years or so. Although Bitcoin contains mechanisms that make it predictable and reliable-the regular production of bitcoins, the publicly verified ledger-these mechanisms still rely on human involvement. Moreover, the Bitcoin code may strip away instances where trust and human overrides are actually preferable, in that they allow considered responses to unanticipated problems. More imperial research is needed to verify and establish the bridging model in bitcoin technology.

In Gandhi, Rupali, et. al (2019), a comparison of the current banking system and the proposed system based on the blockchain technology. To study the feasibility of blockchain technology in the banking system. A proposed model for integration of blockchain into banking. The real time execution of the banking based on blockchain is to be studied further and remains a challenge to the implementers and decision makers. The model needs to be tested further by some use cases in the area.

Yusof, Munir, et. al. (2018) research is aimed at investigating the factors influencing the behavioral intention to adopt blockchain technology by the Malaysian banking institutions. Unified Theory of Acceptance and Use of Technology (UTAUT) with key determinants such as Performance Expectancy, Effort Expectancy, Social Influence and Facilitating Condition has been adopted in this study. Using questionnaire instruments, 149 data from banking respondents in five states have been collected and analyzed. Of the four key determinants, only Effort Expectancy shows an insignificant relationship with the behavioral intention to adopt blockchain technology. the research should be tested with more rigor and with more variables and in other contexts also.

K Meenakshi and George (2018) highlight one of the initiative that can be taken by banks to attain sustainability to the great extent, BlockChain technology being solution to major problems can be implemented in banking process to eliminate unwanted procedures, intermediaries and to go paperless, which enables bank to provide environmental-friendly service. The absence of a common record is a very costly problem, BlockChain does resolve that challenge. Blockchain adoption to save natural resources. Adoption of BlockChain will definitely be a major change in the banking history because it is like banking without much of paper involvement and time consumption being minimal. The accountability factors will be enhanced such that any fraud committed can be detected immediately and actions can be taken immediately. The cost of maintenance of records and other data will also be reduced to great extent because of digitalization of transaction. Blockchain can do to banks what the internet did to media. customer failing to understand the working of Blockchain will still be dependent on physical banks. Certain banks have taken initiatives to adopt Blockchain technology due to ease of operation and research is being carried out in this field. To conclude that the blockchain will reduce the use of natural resources more work should be done analyse the impact of energy requirements in natural resources.

Popova and Butakova (2019) discuss the use of blockchain technology without tokens to protect information about banking transactions, namely, transfer amounts, card details, names of participants, etc. This topic is relevant, since the digital economy is becoming an integral part of modern life. The article analyzes the protection mechanisms of distributed databases, proposes a solution to the problem of maintaining the uniqueness of information in them based on blockchain technology without tokens and gives recommendations on the introduction of blockchain technology into modern banking systems. The blockchain is a tool which at implementation in the Banking system without mining and tokens will considerably simplify processes of maintenance of integrity and uniqueness of information on bank transactions, and its implementation in the processes of smart contracts will allow to reduce number of participants at commission of some transactions. the practical aspect of the proposed solution could be tested empirically.

Mohite (2018) helps to understand of blockchain technology and its emergence, some useful insight on regulatory challenges on the world wide adoption of this new technology in general and India in particular and finally, the purpose of this article is also to enhance the reader's understanding regarding the challenges to be encountered in future particularly by financial service providers in India due to the disruptions caused by rapid advances in technology. This article enunciates the conceptual framework and outlook of blockchain technology in general.

Future Challenges: Development and Applications. This technology is still being developed as experts and practitioners are apprehensive to applications in real life.

Regulatory Challenges: Till now, the one block chain applications have received most of the regulatory attention is Bit-coin or virtual currency to be more precise.

Cyber-Security: Much has been told in the past regarding the dangers and risk associated with the cyber security environment. 
Self-Regulation: Legal codes, laws and regulations can be coded within the digital framework to facilitate automatic implementation and assist the regulators in their attempt to protect the stakeholders

This technology is still being developed as experts and practitioners are apprehensive to applications in real life. Developers are comprehending the mapping benefits accrued from this technology. The future challenges need to be studied in further detail and a workable framework may be derived.

Seretakis (2017) seeks to disentangle the myths from the realities of the so called distributed ledger technology or blockchain revolution and discuss how the legal regime can act both as an impediment and a catalyst to the widespread adoption of the technology. The bankruptcy of Lehman Brothers was followed by the dry-up of liquidity in financial markets and the simultaneous distress of multiple systemically important financial institutions. In their quest to avert an economic calamity, governments and central banks around the world decided to massively intervene in financial markets and expend vast sums of taxpayer money, in order to bailout failing financial institutions, and stabilize the financial system. Shortly after Lehman's bankruptcy, in November 2008, Satoshi Nakamoto, whose real identity remains unknown, driven in part by anger over the financial crisis, published a proposal for a peer-to-peer electronic cash system. Despite the hype surrounding distributed ledger technology, regulatory obstacles can act as an impediment to the widespread adoption of the technology in financial markets. Nonetheless, as experimentation with the technology continues and its potential benefits for financial markets are revealed, policymakers are starting to foster the development of the technology. changes to the regulatory regime, which can act as a catalyst for the application of distributed ledger technology to securities markets.

Ma and Guo (2018) propose a new blockchain-based data privacy management framework. All the countries have different strategies and regulations towards the privacy protection of data in financial scenes, such as the General Data Protection Regulation (GDPR) by European Union (EU). The framework consists of three components: a data privacy classification method according to the characteristics of financial data and a new collaborative filtering-based model and a confirmation data disclosure scheme for customer strategies based on the Nudge Theory. and and propose a set of algorithms for this management framework. future work will incorporate the testing of existing secure and scalable blockchain and the designing a layered architecture for financial applications with hybrid blockchain and feature engineering.

Rega and Riccardi (2017) explore the applications of blockchain technology in the banking industry (in particular, the current initiatives and consortia) and some key issues that must be considered in the banking context. Blockchain is celebrated as "the new Internet of Finance" and is poised to transform multiple sectors, especially the financial services. The World Economic Forum estimated that more than 1.4 billion USD have been invested in this technology. this technology could revolutionize the payment clearing and credit information systems in banks, thus upgrading and transforming them. Blockchain applications also promote the formation of "multi-center, weakly intermediated" scenarios, which will enhance the efficiency of the banking industry. several obstacles, as the technical, regulatory, and other problems of blockchain technology but, perhaps, these ones will ultimately be resolved. The write-up of the white paper needs the rigor of a research paper.

Oh and Shong (2017) suggest reviewing the suitability of the distributed structure of the Blockchain for the automation of financial institution's business process, rather than applying it to the entire financial system or individual financial institutions. The financial institutions in Korea are in the technology verification stage to introduce Blockchain technology. Since there is an insufficient amount of actual measurement data, case study method was adopted. it was discovered that the distributed characteristic of blockchain cannot be applied when actually developing financial services. Blockchain had a potential to improve the existing information handling process of financial institutions. Actually, financial institutions are introducing blockchain to improve information handling process. Currently, Bitcoin-based blockchain is an open network, in which anybody can register, and all the members can participate in the decision-making.

Yeoh (201), examines the key regulatory challenges impacting blockchain in the EU and the US. This investigation helps to draw attention to the technology underpinning virtual currencies. It also highlights other economic potentials flowing from blockchain advancement. The hands-off approach adopted in the EU and the US to a large extent bodes well for future innovative contributions of blockchain especially in the financial services and related sectors and towards enhanced financial inclusiveness. Laws and regulations could impact how far and how fast the technology could develop. Regulatory approaches would therefore need to cleverly balance against its innovative spirits while recognizing the possibility of the technology unintentionally contributing to systemic risks to the financial system. the blockchain technology needs to adapt as per the evolving regulatory framework. 
Table 2: Literature Survey

\begin{tabular}{|c|c|c|c|c|c|c|c|c|c|c|}
\hline$\#$ & Author & $\begin{array}{l}\text { Title of } \\
\text { Paper }\end{array}$ & Year & $\begin{array}{l}\text { Name of } \\
\text { Journal }\end{array}$ & Context & Research Area & Output & Challenges & Research Gap & Database \\
\hline 1 & $\begin{array}{l}\text { Abhish } \\
\text { ek } \\
\text { Gupta, } \\
\text { Stuti } \\
\text { Gupta }\end{array}$ & $\begin{array}{l}\text { Blockcha } \\
\text { in } \\
\text { Technol } \\
\text { ogy: } \\
\text { Applicati } \\
\text { on In } \\
\text { Indian } \\
\text { Banking } \\
\text { Sector }\end{array}$ & $\begin{array}{l}\text { Vol. } \\
19, \\
\text { No. } 2 \\
\text { (July } \\
- \\
\text { Dece } \\
\text { mber } \\
2018 \\
1\end{array}$ & $\begin{array}{l}\text { Delhi } \\
\text { Business } \\
\text { Review }\end{array}$ & $\begin{array}{l}\text { An overview of } \\
\text { Blockchain } \\
\text { Technology with its } \\
\text { benefits and } \\
\text { emphasizing on the } \\
\text { applications of the } \\
\text { technology in the } \\
\text { Indian Banking } \\
\text { Sector. The paper } \\
\text { gives the insight of } \\
\text { various challenges } \\
\text { and global } \\
\text { perspective of } \\
\text { Blockchain } \\
\text { Technology in } \\
\text { banking industry }\end{array}$ & $\begin{array}{l}\text { One disruptive } \\
\text { innovation which is } \\
\text { changing the banking } \\
\text { sector globally is } \\
\text { Blockchain } \\
\text { Technology (BCT) }\end{array}$ & $\begin{array}{l}\text { The study concludes } \\
\text { that, Blockchain will } \\
\text { evolve as a disruptive } \\
\text { force in transforming } \\
\text { Indian Banking Sector } \\
\text { by making banking } \\
\text { transactions more } \\
\text { secure, faster, } \\
\text { transparent, and cost } \\
\text { effective }\end{array}$ & & $\begin{array}{l}\text { The authors have } \\
\text { used secondary data } \\
\text { for the current study. } \\
\text { An empirical } \\
\text { research can be } \\
\text { undertaken in future } \\
\text { to present the } \\
\text { growth of Bitcoin } \\
\text { Technology in India } \\
\text { with respect to other } \\
\text { developing countries. }\end{array}$ & $\begin{array}{l}\text { Google } \\
\text { Scholar }\end{array}$ \\
\hline 2 & $\begin{array}{l}\text { Ye Guo } \\
\text { and } \\
\text { Chen } \\
\text { Liang }\end{array}$ & $\begin{array}{l}\text { Blockcha } \\
\text { in } \\
\text { applicati } \\
\text { on and } \\
\text { outlook } \\
\text { in the } \\
\text { banking } \\
\text { industry }\end{array}$ & 2016 & $\begin{array}{l}\text { Financial } \\
\text { Innovatio } \\
\mathrm{n}(2016) \\
2: 24 \\
\text { Springer } \\
\text { Open }\end{array}$ & $\begin{array}{l}\text { Chinese banking and } \\
\text { fintech markets }\end{array}$ & $\begin{array}{l}\text { Chinese Blockchain } \\
\text { Technology and } \\
\text { Application } \\
\text { Development, } 2016\end{array}$ & $\begin{array}{l}\text { Blockchain } \\
\text { applications also } \\
\text { promote the } \\
\text { formation of "multi- } \\
\text { center, weakly } \\
\text { intermediated" } \\
\text { scenarios, which will } \\
\text { enhance the } \\
\text { efficiency of the } \\
\text { banking industry }\end{array}$ & $\begin{array}{l}\text { Blockchains have a } \\
\text { technological } \\
\text { advantage over } \\
\text { banks as credit } \\
\text { intermediaries, it } \\
\text { is still too early for } \\
\text { this technology to } \\
\text { completely disrupt } \\
\text { the existing } \\
\text { financial } \\
\text { Therefore, a } \\
\text { "multi-center, } \\
\text { weakly } \\
\text { intermediated" } \\
\text { scenario is likely } \\
\text { to emerge. This is } \\
\text { where banks use } \\
\text { blockchain } \\
\text { technology to } \\
\text { improve their } \\
\text { payment clearing } \\
\text { systems and } \\
\text { overcome certain } \\
\text { obstacles in } \\
\text { information } \\
\text { communication, } \\
\text { while also forming } \\
\text { consortiums, } \\
\text { thereby } \\
\text { consolidating their } \\
\text { position }\end{array}$ & $\begin{array}{l}\text { The decentralization } \\
\text { and self-governance } \\
\text { of blockchains dilutes } \\
\text { the concept of } \\
\text { regulation, and has a } \\
\text { critical impact on the } \\
\text { existing system }\end{array}$ & ProQuest \\
\hline 3 & $\begin{array}{l}\text { Dan } \\
\text { Barnes }\end{array}$ & $\begin{array}{l}\text { Blockcha } \\
\text { in } \\
\text { manoeu } \\
\text { vres: } \\
\text { applying } \\
\text { Bitcoin's } \\
\text { technolo } \\
\text { gy to } \\
\text { banking }\end{array}$ & $\begin{array}{l}\text { May- } \\
15\end{array}$ & $\begin{array}{l}\text { The } \\
\text { Banker }\end{array}$ & $\begin{array}{l}\text { banks like UBS, ING } \\
\text { and Nasdaq, are } \\
\text { exploring the } \\
\text { potential of the } \\
\text { technology, be able } \\
\text { to overcome the } \\
\text { challenges that } \\
\text { remain, not least } \\
\text { security and } \\
\text { regulatory issues. }\end{array}$ & $\begin{array}{l}\text { The technology } \\
\text { behind Bitcoin - has } \\
\text { revolutionary } \\
\text { potential. It could } \\
\text { transform almost } \\
\text { every aspect of } \\
\text { commerce and make } \\
\text { stand-ard internet } \\
\text { transactions seem } \\
\text { old fashioned }\end{array}$ & $\begin{array}{l}\text { We have thought } \\
\text { about the memory of } \\
\text { money via a } \\
\text { blockchain. That's an } \\
\text { idea we would love } \\
\text { to drill down into, } \\
\text { but a little bit further } \\
\text { down the road }\end{array}$ & $\begin{array}{l}\text { Can we use this to } \\
\text { replace existing } \\
\text { technology, } \\
\text { whether for } \\
\text { transfers or } \\
\text { payments or in } \\
\text { the security } \\
\text { space? Banks are } \\
\text { making the choice } \\
\text { to move to a } 24 / 7 \\
\text { realtime payment } \\
\text { service: instant } \\
\text { payments but also } \\
\text { instant business. } \\
\text { Discussions of } \\
\text { what kind of } \\
\text { technology to use } \\
\text { is an interesting } \\
\text { dilemma: do you } \\
\text { go for the brand } \\
\text { new, not } \\
\text { completely tested } \\
\text { but very promising } \\
\text { blockchain type of } \\
\text { technology with } \\
\text { everything in it or } \\
\text { proven technology } \\
\text { with databases }\end{array}$ & $\begin{array}{l}\text { Rigor through TAM is } \\
\text { required to analyse } \\
\text { the adoption of the } \\
\text { new technology }\end{array}$ & $\begin{array}{l}\text { Google } \\
\text { Scholar }\end{array}$ \\
\hline
\end{tabular}




\begin{tabular}{|c|c|c|c|c|c|c|c|c|c|c|}
\hline 4 & $\begin{array}{l}\text { Sven } \\
\text { Magnu } \\
\text { s } \\
\text { Degen } \\
\text { er }\end{array}$ & $\begin{array}{l}\text { How } \\
\text { Blockcha } \\
\text { in } \\
\text { affects } \\
\text { Business } \\
\text { Models } \\
\text { in } \\
\text { Internati } \\
\text { onal } \\
\text { Banking }\end{array}$ & $\begin{array}{l}\text { July } \\
10 \text { th, } \\
2018\end{array}$ & $\begin{array}{l}\text { 11th IBA } \\
\text { Bachelor } \\
\text { Thesis } \\
\text { Conferen } \\
\text { ce, } \\
\text { Enschede } \\
\text {, The } \\
\text { Netherlan } \\
\text { ds }\end{array}$ & $\begin{array}{l}\text { This paper compares } \\
\text { the Rabobank and } \\
\text { fintech start-up } \\
\text { Ripple in order to } \\
\text { filter out implications } \\
\text { to the business } \\
\text { model of traditional } \\
\text { banks integrating } \\
\text { blockchain } \\
\text { technology to } \\
\text { process international } \\
\text { payments. Ripple } \\
\text { represents a value } \\
\text { proposition offering } \\
\text { a 'blockchain-as-a- } \\
\text { service' solution, } \\
\text { RippleNet, to which } \\
\text { traditional banks can } \\
\text { simply plug in }\end{array}$ & $\begin{array}{l}\text { Ripple represents a } \\
\text { value proposition } \\
\text { offering a } \\
\text { 'blockchain-as-a- } \\
\text { service' solution, } \\
\text { RippleNet, to which } \\
\text { traditional banks can } \\
\text { simply plug in }\end{array}$ & $\begin{array}{l}\text { The current situation } \\
\text { of the cross-border } \\
\text { payment systems } \\
\text { applied through the } \\
\text { case of the Rabobank } \\
\text { and the information } \\
\text { technology } \\
\text { perspective of } \\
\text { Fiducia GAD. Further } \\
\text { light is spot on the } \\
\text { case of Ripple as } \\
\text { representative of a } \\
\text { blockchain based } \\
\text { solution for a cross- } \\
\text { border payment } \\
\text { system. }\end{array}$ & $\begin{array}{l}\text { The findings } \\
\text { suggest that } \\
\text { blockchain } \\
\text { technology is less } \\
\text { likely to be } \\
\text { successfully } \\
\text { implemented by } \\
\text { traditional banks } \\
\text { in an isolated way. } \\
\text { Instead, it seems } \\
\text { more viable for } \\
\text { banks to } \\
\text { collaborate with } \\
\text { fintech } \\
\text { organizations, like } \\
\text { Ripple, to capture } \\
\text { value from the } \\
\text { blockchain } \\
\text { technology on a } \\
\text { larger scale. }\end{array}$ & $\begin{array}{l}\text { The data collected is } \\
\text { assumed to be clear, } \\
\text { accurate, and of } \\
\text { decent coverage for } \\
\text { the purpose of this } \\
\text { study. the scope of } \\
\text { the targeted data is } \\
\text { considered quite } \\
\text { broad, therefore } \\
\text { finding a decent } \\
\text { expert to interview } \\
\text { on the entire range } \\
\text { of the business } \\
\text { model is difficult }\end{array}$ & $\begin{array}{l}\text { Google } \\
\text { Scholar }\end{array}$ \\
\hline 5 & $\begin{array}{l}\text { Ittay } \\
\text { Eyal }\end{array}$ & $\begin{array}{l}\text { Blockcha } \\
\text { in } \\
\text { Technol } \\
\text { ogy: } \\
\text { Transfor } \\
\text { ming } \\
\text { Libertari } \\
\text { an } \\
\text { Cryptoc } \\
\text { urrency } \\
\text { Dreams } \\
\text { to } \\
\text { Finance } \\
\text { and } \\
\text { Banking } \\
\text { Realities }\end{array}$ & 2017 & $\begin{array}{l}\text { THE I EEE } \\
\text { COMPUT } \\
\text { ER SOCI E } \\
\text { TY: } \\
\text { COVER }\end{array}$ & $\begin{array}{l}\text { The financial } \\
\text { technology (FinTech) } \\
\text { sector sees high } \\
\text { potential value in } \\
\text { cryptocurrency } \\
\text { blockchain protocols, } \\
\text { or distributed-ledger } \\
\text { technology (DLT). } \\
\text { However, the } \\
\text { requirements and } \\
\text { guarantees of } \\
\text { blockchains for } \\
\text { cryptocurrencies do } \\
\text { not match those of } \\
\text { FinTech-from } \\
\text { transaction } \\
\text { throughput to } \\
\text { security primitives } \\
\text { and privacy. The } \\
\text { author explores how } \\
\text { blockchain research } \\
\text { beyond Bitcoin is } \\
\text { closing these gaps } \\
\text { and some of the } \\
\text { challenges that } \\
\text { remain. }\end{array}$ & $\begin{array}{l}\text { Blockchain systems } \\
\text { can be roughly split } \\
\text { into four layers. The } \\
\text { system clients are at } \\
\text { the top, and they } \\
\text { observe an abstract } \\
\text { system state, such as } \\
\text { a balance sheet } \\
\text { stating how much } \\
\text { currency each } \\
\text { account has. This } \\
\text { abstraction is } \\
\text { facilitated by a virtual } \\
\text { machine layer that } \\
\text { accepts transactions } \\
\text { and translates them } \\
\text { into state changes. }\end{array}$ & $\begin{array}{l}\text { new possibilities and } \\
\text { challenges will } \\
\text { continue to arise as } \\
\text { DLT adoption } \\
\text { increases in FinTech, } \\
\text { the full potential of } \\
\text { blockchain } \\
\text { technologies will only } \\
\text { be realized through } \\
\text { direct and effective } \\
\text { collaboration } \\
\text { between the FinTech } \\
\text { industry and the } \\
\text { blockchain scientific } \\
\text { and engineering } \\
\text { community }\end{array}$ & $\begin{array}{l}\text { Blockchain } \\
\text { security relies on } \\
\text { public verifiability } \\
\text { of its integrity. } \\
\text { Each node } \\
\text { observes all blocks } \\
\text { and transactions } \\
\text { and can verify that } \\
\text { the transactions } \\
\text { are legal and the } \\
\text { blocks are } \\
\text { correctly formed. } \\
\text { Nodes do not } \\
\text { create money or } \\
\text { replace it. }\end{array}$ & & IEEE \\
\hline 6 & $\begin{array}{l}\text { Hassan } \\
\mathrm{i}, \\
\text { Hossei } \\
\mathrm{n}, \\
\text { Huang, } \\
\text { Xu, } \\
\text { Silva, } \\
\text { Emma } \\
\text { nuel }\end{array}$ & $\begin{array}{l}\text { Banking } \\
\text { with } \\
\text { blockcha } \\
\text { in-ed big } \\
\text { data }\end{array}$ & $\begin{array}{l}\text { Dec- } \\
18\end{array}$ & $\begin{array}{l}\text { Journal of } \\
\text { Manage } \\
\text { ment } \\
\text { Analytics, } \\
\text { Vol. } 5 \\
\text { Issue 4, } \\
\text { p256-275 }\end{array}$ & $\begin{array}{l}\text { there exists a gap in } \\
\text { research and } \\
\text { development into } \\
\text { blockchain-ed big } \\
\text { data in banking from } \\
\text { an academic } \\
\text { perspective, and this } \\
\text { gap is expected to } \\
\text { have a significant } \\
\text { negative impact on } \\
\text { the adoption and } \\
\text { development of } \\
\text { blockchain } \\
\text { technology for } \\
\text { banking }\end{array}$ & $\begin{array}{l}\text { review of the impact } \\
\text { of blockchain in } \\
\text { banking to date by } \\
\text { summarizing the } \\
\text { opportunities and } \\
\text { challenges from a } \\
\text { bankers perspective }\end{array}$ & $\begin{array}{l}\text { discuss the impact } \\
\text { that big data from } \\
\text { blockchain will have } \\
\text { on banking data } \\
\text { analytics in future } \\
\text { and show the } \\
\text { increasing } \\
\text { importance of } \\
\text { filtering and signal } \\
\text { extraction for the } \\
\text { banking industry }\end{array}$ & & & $\begin{array}{l}\text { Google } \\
\text { Scholar }\end{array}$ \\
\hline 7 & $\begin{array}{l}\text { David } \\
\text { Bates } \\
\text { and } \\
\text { Paul } \\
\text { Miglior } \\
\text { e }\end{array}$ & $\begin{array}{l}\text { Innovate } \\
\text { or } \\
\text { stagnate } \\
: \\
\text { Digitalis } \\
\text { ation in } \\
\text { investm } \\
\text { ent } \\
\text { manage } \\
\text { ment }\end{array}$ & $\begin{array}{l}\text { Jun- } \\
18\end{array}$ & $\begin{array}{l}\text { Journal of } \\
\text { Securities } \\
\text { Operatio } \\
\text { ns \& } \\
\text { Custody } \\
\text { Vol. 10, }\end{array}$ & $\begin{array}{l}\text { This paper explores } \\
\text { the transformative } \\
\text { technologies that will } \\
\text { drive digital isation } \\
\text { efforts in the future, } \\
\text { how asset managers } \\
\text { will need to } \\
\text { differentiate } \\
\text { themselves in the } \\
\text { new digital landscape } \\
\text { and practical steps to } \\
\text { embrace the digital } \\
\text { frontier for } \\
\text { organisations that } \\
\text { are still held back by } \\
\text { legacy technology, } \\
\text { processes and } \\
\text { behaviours }\end{array}$ & $\begin{array}{l}\text { investment } \\
\text { managers have been } \\
\text { digitising information } \\
\text { and processes, but } \\
\text { we have only } \\
\text { recently moved into } \\
\text { a new era where } \\
\text { firms are } \\
\text { reengineering every } \\
\text { facet of the business } \\
\text { upon a digital } \\
\text { foundation }\end{array}$ & $\begin{array}{l}\text { The future state } \\
\text { design options } \\
\text { should be derived } \\
\text { through an open } \\
\text { dialogue with } \\
\text { vendors about their } \\
\text { current and future } \\
\text { product offerings. } \\
\text { Leveraging the } \\
\text { resources and scale } \\
\text { of an external } \\
\text { provider helps asset } \\
\text { managers mitigate } \\
\text { risk by minimising } \\
\text { initial invest ment } \\
\text { and leveraging } \\
\text { technologies tested } \\
\text { by a subset of their } \\
\text { peer group. These } \\
\text { consider ations will }\end{array}$ & & $\begin{array}{l}\text { This paper considers } \\
\text { all the innovative } \\
\text { technologies and give } \\
\text { reasons to either } \\
\text { innovate or stagnate }\end{array}$ & $\begin{array}{l}\text { Google } \\
\text { Scholar }\end{array}$ \\
\hline
\end{tabular}




\begin{tabular}{|c|c|c|c|c|c|c|c|c|c|c|}
\hline & & & & & & & $\begin{array}{l}\text { become increasingly } \\
\text { important } \\
\text { components to a } \\
\text { future state options } \\
\text { anal ysis as the } \\
\text { competitive } \\
\text { landscape shifts to } \\
\text { automation, } \\
\text { processing of } \\
\text { complex data and } \\
\text { sophisticated Al } \\
\text { toolsets }\end{array}$ & & & \\
\hline 8 & $\begin{array}{l}\text { Albeko } \\
\text { v } \\
\text { Adam } \\
\text { Umaro } \\
\text { vich, } \\
\text { Vovch } \\
\text { enko } \\
\text { Natalia }\end{array}$ & $\begin{array}{l}\text { Block } \\
\text { Chain } \\
\text { and } \\
\text { Financial } \\
\text { Controlli } \\
\text { ng in the } \\
\text { System } \\
\text { of } \\
\text { Technol } \\
\text { ogical } \\
\text { Provisio } \\
\text { n of } \\
\text { Large } \\
\text { Corporat } \\
\text { ions' } \\
\text { Economi } \\
\text { c } \\
\text { Security }\end{array}$ & 2017 & $\begin{array}{l}\text { European } \\
\text { Research } \\
\text { Studies } \\
\text { Journal }\end{array}$ & $\begin{array}{l}\text { The research of } \\
\text { current trends and } \\
\text { priorities for the } \\
\text { blockchain } \\
\text { technology use in } \\
\text { order to ensure the } \\
\text { economic security of } \\
\text { large corporate } \\
\text { entities }\end{array}$ & $\begin{array}{l}\text { The subject of the } \\
\text { research is a set of } \\
\text { economic and } \\
\text { organizational and } \\
\text { financial relations } \\
\text { ensuring the financial } \\
\text { controlling } \\
\text { effectiveness in large } \\
\text { corporate entities, } \\
\text { implemented with } \\
\text { the blockchain } \\
\text { technology } \\
\text { application }\end{array}$ & $\begin{array}{l}\text { A conceptual analysis } \\
\text { of the current use of } \\
\text { blockchain } \\
\text { technology has been } \\
\text { used to see the } \\
\text { future road to its } \\
\text { implementation }\end{array}$ & $\begin{array}{l}\text { The application of } \\
\text { blockchain can be } \\
\text { further analysed } \\
\text { in the light of } \\
\text { significant proof }\end{array}$ & $\begin{array}{l}\text { The conducted } \\
\text { analysis of the } \\
\text { blockchain } \\
\text { application risks and } \\
\text { benefits } \\
\text { demonstrates the } \\
\text { need in balancing } \\
\text { risks and benefits of } \\
\text { this technology } \\
\text { application. In the } \\
\text { Russian practice the } \\
\text { named trend is } \\
\text { supported: the most } \\
\text { frequently the } \\
\text { blockchain } \\
\text { technology is used in } \\
\text { financial markets }\end{array}$ & $\begin{array}{l}\text { Google } \\
\text { Scholar }\end{array}$ \\
\hline 9 & $\begin{array}{l}\text { Galyna } \\
\text { Azaren } \\
\text { kova } \\
\text { Iryna } \\
\text { Shkodi } \\
\text { na }\end{array}$ & $\begin{array}{l}\text { The } \\
\text { influenc } \\
\text { e of } \\
\text { financial } \\
\text { technolo } \\
\text { gies on } \\
\text { the } \\
\text { global } \\
\text { financial } \\
\text { system } \\
\text { stability }\end{array}$ & 2018 & $\begin{array}{l}\text { Investme } \\
\text { nt } \\
\text { Manage } \\
\text { ment and } \\
\text { Financial } \\
\text { Innovatio } \\
\text { ns }\end{array}$ & $\begin{array}{l}\text { The study is focussed } \\
\text { on proposing the } \\
\text { ways to reduce the } \\
\text { negative impact of } \\
\text { financial } \\
\text { technologies on the } \\
\text { financial system } \\
\text { stability }\end{array}$ & $\begin{array}{l}\text { The analysis of the } \\
\text { financial technologies } \\
\text { impact on the } \\
\text { stability of financial } \\
\text { system shows that } \\
\text { the lack of } \\
\text { institutional support } \\
\text { for new financial } \\
\text { technologies is the } \\
\text { most important } \\
\text { catalyst for the } \\
\text { financial industry } \\
\text { destabilization and } \\
\text { the formation of } \\
\text { financial bubbles in } \\
\text { various market } \\
\text { segments }\end{array}$ & $\begin{array}{l}\text { This paper considers } \\
\text { the application of } \\
\text { new technology at } \\
\text { global level }\end{array}$ & $\begin{array}{l}\text { The global } \\
\text { scenario does not } \\
\text { allow to study in } \\
\text { an organised and } \\
\text { regulated maner }\end{array}$ & $\begin{array}{l}\text { country specific } \\
\text { proofs are required }\end{array}$ & $\begin{array}{l}\text { Google } \\
\text { Scholar }\end{array}$ \\
\hline 10 & $\begin{array}{l}\text { Yuriy } \\
\text { Petrus } \\
\text { henko } \\
\text { Liudm } \\
\text { yla } \\
\text { Kozare } \\
\text { zenko }\end{array}$ & $\begin{array}{l}\text { The } \\
\text { opportu } \\
\text { nities of } \\
\text { engagin } \\
\mathrm{g} \\
\text { FinTech } \\
\text { compani } \\
\text { es into } \\
\text { the } \\
\text { system } \\
\text { of cross- } \\
\text { border } \\
\text { money } \\
\text { transfers } \\
\text { in } \\
\text { Ukraine }\end{array}$ & 2018 & $\begin{array}{l}\text { Investme } \\
\text { nt } \\
\text { Manage } \\
\text { ment and } \\
\text { Financial } \\
\text { Innovatio } \\
\text { ns }\end{array}$ & $\begin{array}{l}\text { The paper identifies } \\
\text { disruptive challenges } \\
\text { for financial } \\
\text { institutions need to } \\
\text { adapt. The aim of the } \\
\text { research is to } \\
\text { investigate the pros- } \\
\text { pects of FinTech } \\
\text { engagement into the } \\
\text { system of } \\
\text { international } \\
\text { transfers processing } \\
\text { in Ukraine }\end{array}$ & $\begin{array}{l}\text { The research } \\
\text { investigates the value } \\
\text { and the investment } \\
\text { flows structure as } \\
\text { most obvious } \\
\text { indicators of FinTech } \\
\text { and describes types } \\
\text { of payments } \\
\text { relationships there. } \\
\text { The paper considers } \\
\text { relationships } \\
\text { between enterprises, } \\
\text { financial institutions } \\
\text { and individuals, } \\
\text { which are formed in } \\
\text { digital payments }\end{array}$ & $\begin{array}{l}\text { conducting a } \\
\text { comparative analysis } \\
\text { of the regular and } \\
\text { innova- tive cross- } \\
\text { border payment } \\
\text { processes, } \\
\text { developing a } \\
\text { methodology for } \\
\text { evaluating the impact } \\
\text { of FinTech } \\
\text { engagement into the } \\
\text { system of cross- } \\
\text { border pay- ments in } \\
\text { Ukraine, and } \\
\text { investing foreign } \\
\text { experi- ence of } \\
\text { FinTech start-ups } \\
\text { participation in the } \\
\text { in- ternational money } \\
\text { transfers system }\end{array}$ & $\begin{array}{l}\text { The paper shows } \\
\text { that investments } \\
\text { and profits of } \\
\text { cross-border } \\
\text { payment solution } \\
\text { can vary } \\
\text { significantly } \\
\text { between } \\
\text { countries, since } \\
\text { each country has } \\
\text { separate and } \\
\text { diverse national } \\
\text { payment systems. } \\
\text { FinTech can help } \\
\text { to proceed in this } \\
\text { direction enhance } \\
\text { the system and } \\
\text { allow people to } \\
\text { proceed more } \\
\text { effectivel }\end{array}$ & $\begin{array}{l}\text { There is a high } \\
\text { potential of FinTech } \\
\text { for cross-border } \\
\text { payment processing } \\
\text { in near future }\end{array}$ & $\begin{array}{l}\text { Google } \\
\text { Scholar }\end{array}$ \\
\hline 11 & $\begin{array}{l}\text { Luisan } \\
\text { na } \\
\text { Cocco, } \\
\text { Andre } \\
\text { a } \\
\text { Pinna, } \\
\text { Michel } \\
\text { e } \\
\text { March } \\
\text { esi }\end{array}$ & $\begin{array}{l}\text { Banking } \\
\text { on } \\
\text { Blockcha } \\
\text { in: Costs } \\
\text { Savings } \\
\text { Thanks } \\
\text { to the } \\
\text { Blockcha } \\
\text { in }\end{array}$ & $\begin{array}{l}\text { Jun- } \\
17\end{array}$ & $\begin{array}{l}\text { Future } \\
\text { Internet }\end{array}$ & $\begin{array}{l}\text { This paper looks at } \\
\text { the challenges and } \\
\text { opportunities of } \\
\text { implementing } \\
\text { blockchain } \\
\text { technology across } \\
\text { banking, providing } \\
\text { food for thought } \\
\text { about the } \\
\text { potentialities of this } \\
\text { disruptive } \\
\text { technology }\end{array}$ & $\begin{array}{l}\text { defined three } \\
\text { quantities: } \\
\text { "economic } \\
\text { efficiency", } \\
\text { "operational } \\
\text { efficiency", and } \\
\text { "efficient service" }\end{array}$ & $\begin{array}{l}\text { First } \mathrm{EE} \text {, defined as as } \\
\text { the ratio between } \\
\text { the value of bitcoins } \\
\text { mined by the power } \\
\text { consumption of } 1 \\
\mathrm{kWh} \text {, is characterised } \\
\text { by a strong variability } \\
\text { because it is } \\
\text { influenced by the } \\
\text { growing of the } \\
\text { Bitcoin price.the } \\
\text { Bitcoin popularity } \\
\text { and the power } \\
\text { consumption of the }\end{array}$ & $\begin{array}{l}\text { SE, defined as the } \\
\text { ratio between the } \\
\text { number of } \\
\text { transactions } \\
\text { validated by the } \\
\text { power } \\
\text { consumption of } 1 \\
\text { kWh, which } \\
\text { describe how } \\
\text { much electricity } \\
\text { the network } \\
\text { spends to number } \\
\text { of transactions per } \\
\text { block is limited, }\end{array}$ & & ProQuest \\
\hline
\end{tabular}




\begin{tabular}{|c|c|c|c|c|c|c|c|c|c|c|}
\hline & & & & & & & $\begin{array}{l}\text { network. Second, we } \\
\text { found that the OE, } \\
\text { defined as the ratio } \\
\text { between the value of } \\
\text { voluntary fees and } \\
\text { the energy cost of a } \\
\text { transaction, is } \\
\text { currently growing, } \\
\text { indicating that fees } \\
\text { are becoming more } \\
\text { and more important } \\
\text { to assure the } \\
\text { sustainability of the } \\
\text { Bitcoin system. In } \\
\text { fact, mining } \\
\text { operations will be } \\
\text { remunerated only } \\
\text { until the sum of } \\
\text { circulating bitcoins } \\
\text { reaches } 21 \text { million. }\end{array}$ & $\begin{array}{l}\text { and the SE cannot } \\
\text { increase and } \\
\text { perform its main } \\
\text { service, i.e., to } \\
\text { wire bitcoin. }\end{array}$ & & \\
\hline 12 & $\begin{array}{l}\text { Cather } \\
\text { ine } \\
\text { Martin } \\
\text { Christo } \\
\text { pher }\end{array}$ & $\begin{array}{l}\text { THE } \\
\text { BRIDGIN } \\
\text { G } \\
\text { MODEL: } \\
\text { EXPLORI } \\
\text { NG THE } \\
\text { ROLES } \\
\text { OF } \\
\text { TRUST } \\
\text { AND } \\
\text { ENFORC } \\
\text { EMENT } \\
\text { IN } \\
\text { BANKIN } \\
\text { G, } \\
\text { BITCOIN, } \\
\text { AND } \\
\text { THE } \\
\text { BLOCKC } \\
\text { HAIN }\end{array}$ & $\begin{array}{l}\text { Aug- } \\
19\end{array}$ & $\begin{array}{l}\text { HeinOnlin } \\
\text { e }\end{array}$ & $\begin{array}{l}\text { The bridging model is } \\
\text { applied first to } \\
\text { traditional banking, } \\
\text { to illustrate and } \\
\text { analyze the } \\
\text { enforcement } \\
\text { mechanisms } \\
\text { underpinning the } \\
\text { U.S. dollar as } \\
\text { currency and the } \\
\text { banking system as a } \\
\text { whole, and to } \\
\text { demonstrate that the } \\
\text { enforcement } \\
\text { mechanisms } \\
\text { (government backing } \\
\text { and regulation) are } \\
\text { not as robust as } \\
\text { generally believed. } \\
\text { The bridging model is } \\
\text { then applied to } \\
\text { Bitcoin, to show not } \\
\text { only that the system } \\
\text { requires more trust } \\
\text { than is generally } \\
\text { understood, but also } \\
\text { that both currency } \\
\text { and payment } \\
\text { systems benefit from } \\
\text { the involvement of } \\
\text { trusted } \\
\text { intermediaries in } \\
\text { response to } \\
\text { problems and crises. }\end{array}$ & $\begin{array}{l}\text { This article } \\
\text { undertakes a critical } \\
\text { deconstruction of } \\
\text { Bitcoin and the } \\
\text { blockchain, their } \\
\text { themes of democracy } \\
\text { and transparency, } \\
\text { and the idea that } \\
\text { they are trustless. } \\
\text { The article } \\
\text { enforcement and } \\
\text { trust in contract } \\
\text { formation model, } \\
\text { which allows for a } \\
\text { more nuanced } \\
\text { understanding of the } \\
\text { interplay between } \\
\text { conceptualization of } \\
\text { the role of trust in } \\
\text { business and } \\
\text { contracting: the } \\
\text { bridgingthen } \\
\text { proposes a new } \\
\text { framework. }\end{array}$ & $\begin{array}{l}\text { THE BRIDGING } \\
\text { MODEL APPLIED TO } \\
\text { TRADITIONAL } \\
\text { BANKING: As an } \\
\text { illustration of the } \\
\text { bridging model in } \\
\text { application, this Part } \\
\text { applies the model to } \\
\text { traditional banking, } \\
\text { understood roughly } \\
\text { here to mean the } \\
\text { brick-andmortar U.S. } \\
\text { banking system of } \\
\text { the past hundred } \\
\text { years or so. }\end{array}$ & $\begin{array}{l}\text { Although Bitcoin } \\
\text { contains } \\
\text { mechanisms that } \\
\text { make it } \\
\text { predictable and } \\
\text { reliable-the } \\
\text { regular production } \\
\text { of bitcoins, the } \\
\text { publicly verified } \\
\text { ledger-these } \\
\text { mechanisms still } \\
\text { rely on human } \\
\text { involvement. } \\
\text { Moreover, the } \\
\text { Bitcoin code may } \\
\text { strip away } \\
\text { instances where } \\
\text { trust and human } \\
\text { overrides are } \\
\text { actually } \\
\text { preferable, in that } \\
\text { they allow } \\
\text { considered } \\
\text { responses to } \\
\text { unanticipated } \\
\text { problems. }\end{array}$ & $\begin{array}{l}\text { More imperial } \\
\text { research is needed to } \\
\text { verify and establish } \\
\text { the bridging model in } \\
\text { bitcoin technology. }\end{array}$ & $\begin{array}{l}\text { Google } \\
\text { Scholar }\end{array}$ \\
\hline 13 & $\begin{array}{l}\text { Harsha } \\
\text { Gandhi } \\
\text { ' } \\
\text { Rupali } \\
\text { More, } \\
\text { Nainis } \\
\text { ha } \\
\text { Patil }\end{array}$ & $\begin{array}{l}\text { A } \\
\text { BLOCKC } \\
\text { HAIN IN } \\
\text { BANKIN } \\
\text { G } \\
\text { APPLICA } \\
\text { TION }\end{array}$ & $\begin{array}{l}\text { Apr- } \\
19\end{array}$ & $\begin{array}{l}\text { GLOBAL } \\
\text { JOURNAL } \\
\text { FOR } \\
\text { RESEARC } \\
\text { H } \\
\text { ANALYSIS }\end{array}$ & $\begin{array}{l}\text { A comparison of the } \\
\text { current banking } \\
\text { system and the } \\
\text { proposed system } \\
\text { based on the } \\
\text { blockchain } \\
\text { technology }\end{array}$ & $\begin{array}{l}\text { To study the } \\
\text { feasibility of } \\
\text { blockchain } \\
\text { technology in the } \\
\text { banking system }\end{array}$ & $\begin{array}{l}\text { A proposed model } \\
\text { for integration of } \\
\text { blockchain into } \\
\text { banking }\end{array}$ & $\begin{array}{l}\text { The real time } \\
\text { execution of the } \\
\text { banking based on } \\
\text { blockchain is to be } \\
\text { studied further } \\
\text { and remains a } \\
\text { challenge to the } \\
\text { implementers and } \\
\text { decision makers }\end{array}$ & $\begin{array}{l}\text { The model needs to } \\
\text { be tested further by } \\
\text { some use cases in } \\
\text { the area }\end{array}$ & $\begin{array}{l}\text { Google } \\
\text { Scholar }\end{array}$ \\
\hline 14 & $\begin{array}{l}\text { Hayati } \\
\text { Yusof1 } \\
\text {, Mai } \\
\text { Farhan } \\
\text { a Mior } \\
\text { Badrul } \\
\text { Munir } \\
\text { 2, } \\
\text { Zulnur } \\
\text { haini } \\
\text { Zolkapl } \\
\text { y et. } \\
\text { al. }\end{array}$ & $\begin{array}{l}\text { Behavior } \\
\text { al } \\
\text { Intentio } \\
\mathrm{n} \text { to } \\
\text { Adopt } \\
\text { Blockcha } \\
\text { in } \\
\text { Technol } \\
\text { ogy: } \\
\text { Viewpoi } \\
\text { nt of the } \\
\text { Banking } \\
\text { Instituti } \\
\text { ons in } \\
\text { Malaysia }\end{array}$ & $\begin{array}{l}\text { Oct- } \\
18\end{array}$ & $\begin{array}{l}\text { nternatio } \\
\text { nal } \\
\text { Journal of } \\
\text { Advanced } \\
\text { Scientific } \\
\text { Research } \\
\text { and } \\
\text { Manage } \\
\text { ment, } \\
\text { Volume } 3 \\
\text { Issue } 10\end{array}$ & $\begin{array}{l}\text { This research is } \\
\text { aimed at } \\
\text { investigating the } \\
\text { factors influencing } \\
\text { the behavioral } \\
\text { intention to adopt } \\
\text { blockchain } \\
\text { technology by the } \\
\text { Malaysian banking } \\
\text { institutions. Unified } \\
\text { Theory of } \\
\text { Acceptance and Use } \\
\text { of Technology } \\
\text { (UTAUT) with key } \\
\text { determinants such as } \\
\text { Performance } \\
\text { Expectancy, Effort } \\
\text { Expectancy, Social }\end{array}$ & $\begin{array}{l}\text { Using questionnaire } \\
\text { instruments, } 149 \\
\text { data from banking } \\
\text { respondents in five } \\
\text { states have been } \\
\text { collected and } \\
\text { analyzed }\end{array}$ & $\begin{array}{l}\text { Of the four key } \\
\text { determinants, only } \\
\text { Effort Expectancy } \\
\text { shows an } \\
\text { insignificant } \\
\text { relationship with the } \\
\text { behavioral intention } \\
\text { to adopt blockchain } \\
\text { technology }\end{array}$ & $\begin{array}{l}\text { the research } \\
\text { should be tested } \\
\text { with more rigor } \\
\text { and with more } \\
\text { variables and in } \\
\text { other contexts } \\
\text { also }\end{array}$ & & $\begin{array}{l}\text { Google } \\
\text { Scholar }\end{array}$ \\
\hline
\end{tabular}




\begin{tabular}{|c|c|c|c|c|c|c|c|c|c|c|}
\hline & & & & & $\begin{array}{l}\text { Influence and } \\
\text { Facilitating Condition } \\
\text { has been adopted in } \\
\text { this study }\end{array}$ & & & & & \\
\hline 15 & $\begin{array}{l}\text { MEEN } \\
\text { AKSHI } \\
\text { K, } \\
\text { ANEET } \\
\text { TA } \\
\text { ROSE } \\
\text { GEOR } \\
\text { GE et. } \\
\text { al. }\end{array}$ & $\begin{array}{l}\text { GREEN } \\
\text { BANKIN } \\
\text { G } \\
\text { THROUG } \\
\text { H } \\
\text { BLOCKC } \\
\text { HAIN }\end{array}$ & $\begin{array}{l}\text { Jan- } \\
18\end{array}$ & $\begin{array}{l}\text { Internatio } \\
\text { nal } \\
\text { Journal of } \\
\text { Research } \\
\text { and } \\
\text { Analytical } \\
\text { Reviews }\end{array}$ & $\begin{array}{l}\text { This paper highlights } \\
\text { one of the initiative } \\
\text { that can be taken by } \\
\text { banks to attain } \\
\text { sustainability to the } \\
\text { great extent, } \\
\text { BlockChain } \\
\text { technology being } \\
\text { solution to major } \\
\text { problems can be } \\
\text { implemented in } \\
\text { banking process to } \\
\text { eliminate unwanted } \\
\text { procedures, } \\
\text { intermediaries and to } \\
\text { go paperless, which } \\
\text { enables bank to } \\
\text { provide } \\
\text { environmental- } \\
\text { friendly service. The } \\
\text { absence of a } \\
\text { common record is a } \\
\text { very costly problem, } \\
\text { BlockChain does } \\
\text { resolve that } \\
\text { challenge. }\end{array}$ & $\begin{array}{l}\text { Blockchain adoption } \\
\text { to save natural } \\
\text { resources }\end{array}$ & $\begin{array}{l}\text { Adoption of } \\
\text { BlockChain will } \\
\text { definitely be a major } \\
\text { change in the } \\
\text { banking history } \\
\text { because it is like } \\
\text { banking without } \\
\text { much of paper } \\
\text { involvement and } \\
\text { time consumption } \\
\text { being minimal. The } \\
\text { accountability factors } \\
\text { will be enhanced } \\
\text { such that any fraud } \\
\text { committed can be } \\
\text { detected } \\
\text { immediately and } \\
\text { actions can be taken } \\
\text { immediately. The } \\
\text { cost of maintenance } \\
\text { of records and other } \\
\text { data will also be } \\
\text { reduced to great } \\
\text { extent because of } \\
\text { digitalization of } \\
\text { transaction. } \\
\text { BlockChain can do to } \\
\text { banks what the } \\
\text { internet did to media }\end{array}$ & $\begin{array}{l}\text { customer failing to } \\
\text { understand the } \\
\text { working of } \\
\text { BlockChain will } \\
\text { still be dependent } \\
\text { on physical banks. } \\
\text { Certain banks } \\
\text { have taken } \\
\text { initiatives to adopt } \\
\text { BlockChain } \\
\text { technology due to } \\
\text { ease of operation } \\
\text { and research is } \\
\text { being carried out } \\
\text { in this field }\end{array}$ & $\begin{array}{l}\text { To conclude that the } \\
\text { blockchain will } \\
\text { reduce the use of } \\
\text { natural resources } \\
\text { more work should be } \\
\text { done analyse the } \\
\text { impact of energy } \\
\text { requirements in } \\
\text { natural resources }\end{array}$ & $\begin{array}{l}\text { Google } \\
\text { Scholar }\end{array}$ \\
\hline 16 & $\begin{array}{l}\text { Natalia } \\
\text { A. } \\
\text { Popov } \\
\text { a, } \\
\text { Natalia } \\
\text { G. } \\
\text { Butako } \\
\text { va }\end{array}$ & $\begin{array}{l}\text { Researc } \\
\mathrm{h} \text { of a } \\
\text { Possibilit } \\
\text { y of } \\
\text { Using } \\
\text { Blockcha } \\
\text { in } \\
\text { Technol } \\
\text { ogy } \\
\text { without } \\
\text { Tokens } \\
\text { to } \\
\text { Protect } \\
\text { Banking } \\
\text { Transact } \\
\text { ions }\end{array}$ & 2019 & IEEE & $\begin{array}{l}\text { this paper discusses } \\
\text { the use of Blockchain } \\
\text { technology without } \\
\text { tokens to protect } \\
\text { information about } \\
\text { banking transactions, } \\
\text { namely, transfer } \\
\text { amounts, card } \\
\text { details, names of } \\
\text { participants, etc. This } \\
\text { topic is relevant, } \\
\text { since the digital } \\
\text { economy is } \\
\text { becoming an integral } \\
\text { part of modern life }\end{array}$ & $\begin{array}{l}\text { The article analyzes } \\
\text { the protection } \\
\text { mechanisms of } \\
\text { distributed } \\
\text { databases, proposes } \\
\text { a solution to the } \\
\text { problem of } \\
\text { maintaining the } \\
\text { uniqueness of } \\
\text { information in them } \\
\text { based on Blockchain } \\
\text { technology without } \\
\text { tokens and gives } \\
\text { recommendations on } \\
\text { the } \\
\text { introduction of } \\
\text { Blockchain } \\
\text { technology into } \\
\text { modern banking } \\
\text { systems }\end{array}$ & $\begin{array}{l}\text { the Blockchain is a } \\
\text { tool which at } \\
\text { implementation in } \\
\text { the Banking system } \\
\text { without mining and } \\
\text { tokens will } \\
\text { considerably simplify } \\
\text { processes of } \\
\text { maintenance of } \\
\text { integrity and } \\
\text { uniqueness of } \\
\text { information on bank } \\
\text { transactions, and its } \\
\text { implementation in } \\
\text { the processes of } \\
\text { smart contracts will } \\
\text { allow to reduce } \\
\text { number of } \\
\text { participants at } \\
\text { commission of some } \\
\text { transactions }\end{array}$ & & $\begin{array}{l}\text { the practical aspect } \\
\text { of the proposed } \\
\text { solution could be } \\
\text { tested imperically }\end{array}$ & IEEE \\
\hline
\end{tabular}




\begin{tabular}{|c|c|c|c|c|c|c|c|c|c|c|}
\hline 17 & $\begin{array}{l}\text { Vikram } \\
\text { Mohit } \\
\text { e }\end{array}$ & $\begin{array}{l}\text { Reducin } \\
\text { g } \\
\text { Uncertai } \\
\text { nty in } \\
\text { Trade } \\
\text { and } \\
\text { Deciphe } \\
\text { ring } \\
\text { Future } \\
\text { Challeng } \\
\text { es in } \\
\text { Banking } \\
\text { Industry } \\
\text { Through } \\
\text { Applicati } \\
\text { on of } \\
\text { Blockcha } \\
\text { in } \\
\text { Technol } \\
\text { ogy }\end{array}$ & $\begin{array}{l}\text { Jul- } \\
18\end{array}$ & $\begin{array}{l}\text { Internatio } \\
\text { nal } \\
\text { Bulletin } \\
\text { of } \\
\text { Manage } \\
\text { ment and } \\
\text { Economic } \\
\text { s }\end{array}$ & $\begin{array}{l}\text { to understand of } \\
\text { blockchain } \\
\text { technology and its } \\
\text { emergence, some } \\
\text { useful insight on } \\
\text { regulatory challenges } \\
\text { on the world wide } \\
\text { adoption of this new } \\
\text { technology in general } \\
\text { and India in } \\
\text { particular and finally, } \\
\text { the purpose of this } \\
\text { article is also to } \\
\text { enhance the reader's } \\
\text { understanding } \\
\text { regarding the } \\
\text { challenges to be } \\
\text { encountered in } \\
\text { future particularly by } \\
\text { financial service } \\
\text { providers in India } \\
\text { due to the } \\
\text { disruptions caused } \\
\text { by rapid advances in } \\
\text { technology }\end{array}$ & $\begin{array}{l}\text { This article } \\
\text { enunciates the } \\
\text { conceptual } \\
\text { framework and } \\
\text { outlook of blockchian } \\
\text { technology in general }\end{array}$ & $\begin{array}{l}\text { Future Challenges: } \\
\text { Development and } \\
\text { Applications: This } \\
\text { technology is still } \\
\text { been developed as } \\
\text { experts and } \\
\text { practitioners are } \\
\text { apprehensive to } \\
\text { applications in real } \\
\text { life. Regulatory } \\
\text { Challenges: Till now, } \\
\text { the one block chain } \\
\text { applications has } \\
\text { received most of the } \\
\text { regulatory } \\
\text { attention is Bit-coin } \\
\text { or virtual currency to } \\
\text { be more precise. } \\
\text { Cyber-security: Much } \\
\text { has been told in the } \\
\text { past regarding the } \\
\text { dangers and risk } \\
\text { associated with the } \\
\text { cybersecurity } \\
\text { environment. } \\
\text { Self-Regulation:Legal } \\
\text { codes, laws and } \\
\text { regulations can be } \\
\text { coded within the } \\
\text { digital framework to } \\
\text { facilitate } \\
\text { automatic } \\
\text { implementation and } \\
\text { assist the regulators } \\
\text { in their attempt to } \\
\text { protect the } \\
\text { stakeholders }\end{array}$ & $\begin{array}{l}\text { This technology is } \\
\text { still been } \\
\text { developed as } \\
\text { experts and } \\
\text { practitioners are } \\
\text { apprehensive to } \\
\text { applications in } \\
\text { real life. } \\
\text { Developers are } \\
\text { comprehending } \\
\text { the mapping } \\
\text { benefits accrued } \\
\text { from this } \\
\text { technology }\end{array}$ & $\begin{array}{l}\text { The future challenges } \\
\text { need to be studied in } \\
\text { further detail and a } \\
\text { workable framework } \\
\text { ma be derived }\end{array}$ & $\begin{array}{l}\text { Google } \\
\text { Scholar }\end{array}$ \\
\hline 18 & $\begin{array}{l}\text { ALEXA } \\
\text { NDRO } \\
\text { S } \\
\text { SERET } \\
\text { AKIS }\end{array}$ & $\begin{array}{l}\text { BLOCKC } \\
\text { HAIN, } \\
\text { SECURIT } \\
\text { IES } \\
\text { MARKET } \\
\text { S AND } \\
\text { CENTRA } \\
\text { L } \\
\text { BANKIN } \\
\text { G }\end{array}$ & 2017 & $\begin{array}{l}\text { JOURNAL } \\
\text { OF } \\
\text { FINANCIA } \\
\text { L } \\
\text { ECONOMI } \\
\text { CS } 425 \\
(2012)\end{array}$ & $\begin{array}{l}\text { This paper will seek } \\
\text { to disentangle the } \\
\text { myths from the } \\
\text { realities of the } \\
\text { socalled distributed } \\
\text { ledger technology or } \\
\text { blockchain revolution } \\
\text { and discuss how the } \\
\text { legal regime can act } \\
\text { both as an } \\
\text { impediment and a } \\
\text { catalyst to the } \\
\text { widespread adoption } \\
\text { of the technology. }\end{array}$ & $\begin{array}{l}\text { The bankruptcy of } \\
\text { Lehman Brothers was } \\
\text { followed by the dry- } \\
\text { up of liquidity in } \\
\text { financial markets and } \\
\text { the } \\
\text { simultaneous distress } \\
\text { of multiple } \\
\text { systemically } \\
\text { important financial } \\
\text { institutions. In their } \\
\text { quest to avert an } \\
\text { economic calamity, } \\
\text { governments and } \\
\text { central banks around } \\
\text { the world } \\
\text { decided to massively } \\
\text { intervene in financial } \\
\text { markets and expend } \\
\text { vast sums of taxpayer } \\
\text { money, in order to } \\
\text { bailout failing } \\
\text { financial institutions, } \\
\text { and stabilize the } \\
\text { financial } \\
\text { system. Shortly after } \\
\text { Lehman's } \\
\text { bankruptcy, in } \\
\text { November } 2008 \text {, } \\
\text { Satoshi Nakamoto, } \\
\text { whose real identity } \\
\text { remains unknown, } \\
\text { driven in part by } \\
\text { anger over the } \\
\text { financial crisis, } \\
\text { published a proposal } \\
\text { for a peer-to-peer } \\
\text { electronic cash } \\
\text { system. }\end{array}$ & $\begin{array}{l}\text { Despite the hype } \\
\text { surrounding } \\
\text { distributed ledger } \\
\text { technology, } \\
\text { regulatory obstacles } \\
\text { can act as an } \\
\text { impediment to the } \\
\text { widespread adoption } \\
\text { of the technology in } \\
\text { financial markets. } \\
\text { Nonetheless, as } \\
\text { experimentation with } \\
\text { the technology } \\
\text { continues and its } \\
\text { potential benefits for } \\
\text { financial markets are } \\
\text { revealed, } \\
\text { policymakers are } \\
\text { starting to foster the } \\
\text { development of the } \\
\text { technology }\end{array}$ & $\begin{array}{l}\text { changes to the } \\
\text { regulatory regime, } \\
\text { which can act as a } \\
\text { catalyst for the } \\
\text { application of } \\
\text { distributed ledger } \\
\text { technology to } \\
\text { securities markets }\end{array}$ & & $\begin{array}{l}\text { Google } \\
\text { Scholar }\end{array}$ \\
\hline 19 & $\begin{array}{l}\text { Shengl } \\
\text { an } \\
\text { Ma1, } \\
\text { Chaoni } \\
\text { an }\end{array}$ & $\begin{array}{l}\text { Nudging } \\
\text { Data } \\
\text { Privacy } \\
\text { Manage } \\
\text { ment of }\end{array}$ & 2018 & $\begin{array}{l}\text { Internatio } \\
\text { nal } \\
\text { Symposiu } \\
\text { m on } \\
\text { Pervasive }\end{array}$ & $\begin{array}{l}\text { this paper proposes a } \\
\text { new blockchain- } \\
\text { based data privacy } \\
\text { management } \\
\text { framework }\end{array}$ & $\begin{array}{l}\text { All the countries have } \\
\text { different strategies } \\
\text { and regulations } \\
\text { towards the privacy } \\
\text { protection of data in }\end{array}$ & $\begin{array}{l}\text { The framework } \\
\text { consists of three } \\
\text { components: a data } \\
\text { privacy classification } \\
\text { method according to }\end{array}$ & & $\begin{array}{l}\text { future work will } \\
\text { incorporate the } \\
\text { testing of existing } \\
\text { secure and scalable } \\
\text { blockchain and the }\end{array}$ & $\begin{array}{l}\text { Google } \\
\text { Scholar }\end{array}$ \\
\hline
\end{tabular}




\begin{tabular}{|c|c|c|c|c|c|c|c|c|c|c|}
\hline & $\begin{array}{l}\text { Guo, } \\
\text { et. al. }\end{array}$ & $\begin{array}{l}\text { Open } \\
\text { Banking } \\
\text { based } \\
\text { on } \\
\text { Blockcha } \\
\text { in }\end{array}$ & & $\begin{array}{l}\text { Systems, } \\
\text { Algorithm } \\
\text { s and } \\
\text { Networks }\end{array}$ & & $\begin{array}{l}\text { financial scenes, such } \\
\text { as the General Data } \\
\text { Protection Regulation } \\
\text { (GDPR) by European } \\
\text { Union (EU) }\end{array}$ & $\begin{array}{l}\text { the characteristics of } \\
\text { financial data and a } \\
\text { new } \\
\text { collaborativefiltering- } \\
\text { based model and a } \\
\text { confirmation data } \\
\text { disclosure scheme } \\
\text { for customer } \\
\text { strategies based on } \\
\text { the Nudge Theory. } \\
\text { and and propose a } \\
\text { set of algorithms for } \\
\text { this } \\
\text { management } \\
\text { framework }\end{array}$ & & $\begin{array}{l}\text { designing a layered } \\
\text { architecture for } \\
\text { financial applications } \\
\text { with hybrid } \\
\text { blockchain and } \\
\text { feature engineering }\end{array}$ & \\
\hline 20 & $\begin{array}{l}\text { Federi } \\
\text { co } \\
\text { Giovan } \\
\text { ni } \\
\text { Rega, } \\
\text { Nunzia } \\
\text { Riccar } \\
\text { di }\end{array}$ & $\begin{array}{l}\text { Blockcha } \\
\text { in in the } \\
\text { banking } \\
\text { industry: } \\
\text { an } \\
\text { Overvie } \\
\text { w }\end{array}$ & & $\begin{array}{l}\text { White } \\
\text { Paper }\end{array}$ & $\begin{array}{l}\text { To explore the } \\
\text { applicationsof } \\
\text { blockchain } \\
\text { technology in the } \\
\text { banking industry (in } \\
\text { particular, the } \\
\text { current initiatives } \\
\text { and consortia) and } \\
\text { some key issues that } \\
\text { must be considered } \\
\text { in the banking } \\
\text { context }\end{array}$ & $\begin{array}{l}\text { Blockchain is } \\
\text { celebrated as "the } \\
\text { new Internet of } \\
\text { Finance" and is } \\
\text { poised to transform } \\
\text { multiple sectors, } \\
\text { especially the } \\
\text { financial services. The } \\
\text { World Economic } \\
\text { Forum estimated that } \\
\text { more than } 1.4 \text { billion } \\
\text { USD have been } \\
\text { invested in this } \\
\text { technology }\end{array}$ & $\begin{array}{l}\text { this technology could } \\
\text { revolutionize the } \\
\text { payment clearing and } \\
\text { credit information } \\
\text { systems in banks, } \\
\text { thus upgrading and } \\
\text { transforming them. } \\
\text { Blockchain } \\
\text { applications also } \\
\text { promote the } \\
\text { formation of "multi- } \\
\text { center, weakly } \\
\text { intermediated" } \\
\text { scenarios, which will } \\
\text { enhance the } \\
\text { efficiency of the } \\
\text { banking industry }\end{array}$ & $\begin{array}{l}\text { several obstacles, } \\
\text { as the technical, } \\
\text { regulatory, and } \\
\text { other problems of } \\
\text { blockchain } \\
\text { technology but, } \\
\text { perhaps, these } \\
\text { ones will } \\
\text { ultimately be } \\
\text { resolved. }\end{array}$ & $\begin{array}{l}\text { The writeup of the } \\
\text { white paper needs } \\
\text { the rigor of a } \\
\text { research paper }\end{array}$ & $\begin{array}{l}\text { Google } \\
\text { Scholar }\end{array}$ \\
\hline 21 & $\begin{array}{l}\text { JaeShu } \\
\text { p Oh, } \\
\text { Ilho } \\
\text { Shong }\end{array}$ & $\begin{array}{l}\text { A case } \\
\text { study on } \\
\text { business } \\
\text { model } \\
\text { innovati } \\
\text { ons } \\
\text { using } \\
\text { Blockcha } \\
\text { in: } \\
\text { focusing } \\
\text { on } \\
\text { financial } \\
\text { instituti } \\
\text { ons }\end{array}$ & 2017 & $\begin{array}{l}\text { Asia } \\
\text { Pacific } \\
\text { Journal of } \\
\text { Innovatio } \\
\mathrm{n} \text { and } \\
\text { Entrepren } \\
\text { eurship, } \\
\text { Vol. } 11 \\
\text { No. } 3\end{array}$ & $\begin{array}{l}\text { This paper suggests } \\
\text { reviewing the } \\
\text { suitability of the } \\
\text { distributed structure } \\
\text { of the Blockchain for } \\
\text { the automation of } \\
\text { financial institution's } \\
\text { business process, } \\
\text { rather than applying } \\
\text { it to the entire } \\
\text { financial systemor } \\
\text { individual financial } \\
\text { institutions. }\end{array}$ & $\begin{array}{l}\text { The financial } \\
\text { institutions in Korea } \\
\text { are in the technology } \\
\text { verification stage to } \\
\text { introduce Blockchain } \\
\text { technology. Since } \\
\text { there is an } \\
\text { insufficient amount } \\
\text { of actual } \\
\text { measurement data, } \\
\text { case study method } \\
\text { was adopted. }\end{array}$ & $\begin{array}{l}\text { it was discovered } \\
\text { that the distributed } \\
\text { characteristic of } \\
\text { Blockchain cannot be } \\
\text { applied when } \\
\text { actually developing } \\
\text { financial services }\end{array}$ & $\begin{array}{l}\text { Blockchain had a } \\
\text { potential to } \\
\text { improve the } \\
\text { existing } \\
\text { information } \\
\text { handling process } \\
\text { of financial } \\
\text { institutions. } \\
\text { Actually, financial } \\
\text { institutions are } \\
\text { introducing } \\
\text { Blockchain to } \\
\text { improve } \\
\text { information } \\
\text { handling process. } \\
\text { Currently, Bitcoin- } \\
\text { based Blockchain } \\
\text { is an open } \\
\text { network, in which } \\
\text { anybody can } \\
\text { register, and all } \\
\text { the members can } \\
\text { participate in the } \\
\text { decision-making }\end{array}$ & & Emerald \\
\hline 22 & $\begin{array}{l}\text { Peter } \\
\text { Yeoh }\end{array}$ & $\begin{array}{l}\text { Regulato } \\
\text { ry Issues } \\
\text { in } \\
\text { Blockcha } \\
\text { in } \\
\text { Technol } \\
\text { ogy }\end{array}$ & 2017 & $\begin{array}{l}\text { Journal of } \\
\text { Financial } \\
\text { Regulatio } \\
\mathrm{n} \text { and } \\
\text { Complian } \\
\text { ce, Vol. } \\
25\end{array}$ & $\begin{array}{l}\text { This paper examines } \\
\text { the key regulatory } \\
\text { challenges impacting } \\
\text { blockchains in the EU } \\
\text { and the US. }\end{array}$ & $\begin{array}{l}\text { This investigation } \\
\text { helps to draw } \\
\text { attention to the } \\
\text { technology } \\
\text { underpinning virtual } \\
\text { currencies. It also } \\
\text { highlights other } \\
\text { economic potentials } \\
\text { flowing from } \\
\text { blockchain } \\
\text { advancement. }\end{array}$ & $\begin{array}{l}\text { The hands-off } \\
\text { approach adopted in } \\
\text { the EU and the US to } \\
\text { a large extent bodes } \\
\text { well for future } \\
\text { innovative } \\
\text { contributions of } \\
\text { blockchains } \\
\text { especially in the } \\
\text { financial services and } \\
\text { related sectors and } \\
\text { towards enhanced } \\
\text { financial } \\
\text { inclusiveness. }\end{array}$ & $\begin{array}{l}\text { Laws and } \\
\text { regulations could } \\
\text { impact how far } \\
\text { and how fast the } \\
\text { technology could } \\
\text { develop. } \\
\text { Regulatory } \\
\text { approaches would } \\
\text { therefore need to } \\
\text { cleverly balance } \\
\text { against its } \\
\text { innovative spirits } \\
\text { while recognizing } \\
\text { the possibility of } \\
\text { the technology } \\
\text { unintentionally } \\
\text { contributing to } \\
\text { systemic risks to } \\
\text { the financial } \\
\text { system }\end{array}$ & $\begin{array}{l}\text { the blockchain } \\
\text { technology needs to } \\
\text { adapt as per the } \\
\text { evolving regulatory } \\
\text { framework }\end{array}$ & Emerald \\
\hline
\end{tabular}




\section{BLOCKCHAIN AND THE SHARING ECONOMY: PATHS FOR FUTURE RESEARCH}

Academic attempts to investigate the potential of blockchain technology in replacing third parties are made (Bogneretal.,2016; Sunetal.,2016), the success of such attempts is rather limited and primarily focuses on the context of online interaction and transaction transparency (Huckle et al., 2016). Actual connections of the blockchain with the physical world are hardly addressed in the literature so far, particularly with regard to trust. A noteworthy exception is a recent paper by Pazaitis, De Filippi and Kostakis (2017), who approach the issue of "trusted interactions on top of the trustless blockchain technology" by the introduction of a so-called proof-of-value concept to verify the value of a (human) contribution to a sharing ecosystem.

Following this promising work, future research should address the design of trusted interfaces to support the successful implementation of blockchain-based sharing platforms - not only for online, but also for off line interactions. Overcoming the trust frontier without the necessity of trusted third parties will be a major challenge for future work and may provide platform operators with a business opportunity. Moreover, to better understand consumers' perception of blockchain-based platforms, particularly with regard to the formation of trust, future research should address the conceptualization and development of adequate measurement instruments for trust in blockchain-based algorithms. Overall, we call for high degrees of rigor in the specification and discussion of the concept of trust. It is of utmost importance for both theory and practice to clearly understand the concepts, dimensions, and targets of trust to develop meaningful results. To successfully translate the hype around blockchain technology into viable sharing economy applications, both practical and research efforts will be urgently needed.

\section{DISCUSSION AND CONCLUSION}

In this paper, we laid the foundation for further research into the study and implementation of the blockchain technology and their integration into the banking sector. For this purpose, this paper can be considered a starting point in various research domains that will eventually analyze the various research points representing different dimensions of blockchain technology and its application and acceptance in the banking sector. For instance, finance researchers could be interested in the changes blockchain cause in the banking sector, economics researchers could further look into the consequences for the entire economy, or necessary policy changes. Digital transformation is increasingly accelerating developments in several economies and industries, similar phenomena are likely to similarly shape other industries.

We propose a classification scheme for banking practitioners to evaluate their efforts at the interaction between banks and new technology. Managers can gain insights into the shared practices and related outcomes. Considering the number of co-operations, it is understood and instituted as an eligible strategy for promoting innovation. We also found that both parties benefit from the model, and complement each other's strengths and weaknesses. Technology play a crucial role and don't remain the silent, lesser partner in co-operations. Thus, alliances are the predominant form of cooperation in our empirical database, and acquisitions and incubations only play minor roles. We can say that the Blockchain is going to bring a serious transformation within the banking sector. A secure distributed database of client information should be developed and shared by the different bank which will help in reducing time, effort and cost in inter-bank transactions. The information on that may be verified and audited at any time. All of the transaction data that is integrated with

a Blockchain is verified by miners and consensus rules. In a bid to evolve towards cashless society this is an appropriate time for initiating suitable efforts towards digitizing the Indian rupees through Blockchain technology. In the coming years, Blockchain will evolve as a disruptive force in transforming the Indian banking sector by making banking transaction faster, transparent. We can powerfully advocate that point is ripe for adoption of Blockchain in the Banking Sector.

\section{REFERENCES}

Abramova, O., Krasnova, H., Shavanova, T., Fuhrer, A., Buxmann, P., (2016). Impression management in the sharing economy: understanding the effect of response strategy to. Die Unternehmung - Swiss Journal of Business Research Practice, 70, 58-73. https://doi. org/10.5771/0042-059X2016-1-58.

Abramova, O., Shanvanova, T., Fuhrer, A., Krasnova, H., Buxmann, P., (2015). Understanding the sharing economy: the role of response to negative reviews in the peer-to-peer accommodation sharing network. In: ECIS 2015 Proceedings.

Ahangama, S., Poo, D.C.C., (2016). Credibility of algorithm based decentralized computer networks governing personal finances: the case of cryptocurrency. In: HCIBGO 2016 Proceedings. 165-176. doi:10.1007/978-3-319-39396-4

Al Khalil, F., Butler, T., O’Brien, L., Ceci, M., (2017). Trust in smart contracts is a process, as well. In: Brenner, M., Rohloff, K., Bonneau, J., Miller, A., Ryan, P.Y.A., Teague, V., Bracciali, A., Sala, M., Pintore, F., Jakobsson, M. (Eds.), Financial Cryptography and Data Security. Springer International Publishing, Cham, 510-519. 
Albinsson, P.A., Perera, Y., (2012). Alternative marketplaces in the 21st century: building community through sharing events. Journal of Consumer Behaviour, 11, 303-315. https://doi.org/10.1002/cb.1389.

Albiston, G., Osman, T., Peytchev, E., (2014). Modelling trust in semantic web applications. In: UKSim 2014 Proceedings. 440-445. doi:10.1109/ UKSim.2014.62

Umarovich, A.A., Natalia, V. (2017). Blockchain and financial controlling in the system of technological provision of large corporations' economic security. European Research Studies Journal, 265-288.

Alexopoulos, N., Daubert, J., Muhlhauser, M., Habib, S.M., (2017). Beyond the hype: On using blockchains in trust management for authentication. In: Proceedings - 16th IEEE International Conference on Trust, Security and Privacy in Computing and Communications, 11th IEEE International Conference on Big Data Science and Engineering and 14th IEEE International Conference on Embedded Software and Systems. 546-553. doi:10.1109/Trustcom/BigDataSE/ICESS.2017.283

Aufmann, C., (2016). Designing for trust : airbnb design [WWW Document]. Airbnb, URL. http://airbnb.design/designing-for-trust/.

Avital, M., King, J.L., Beck, R., Rossi, M., Teigland, R., (2016). Jumping on the blockchain bandwagon: lessons of the past and outlook to the future panel. In: ICIS 2016 Proceedings. Ba, S., Pavlou, P.A.

Baek, C., Elbeck, M., (2014). Bitcoins as an investment or speculative vehicle? A first look. Applied Economics Letters, 1-5, https://doi.org/10.1080/13504851.2014.916379.

Ballús-Armet, I., Shaheen, S.A., Clonts, K., Weinzimmer, D., (2014). Peer-to-peer carsharing. Transportation Research Journal, $2416,27-36$. https://doi.org/ 10.3141/2416-04.

Bardhi, F., Eckhardt, G.M., (2012). Access-based consumption: the case of car sharing. Journal of Consumer Research, 39, 881-898. https://doi.org/10.1086/666376.

David, B. and Migliore, P., (2018). Innovate or stagnate: digitalisation in investment management. Journal of Securities Operations \& Custody, 10, 18-28.

Beck, R., Stenum Czepluch, J., Lollike, N., Malone, S., (2016). Blockchain - the gateway to trust-free cryptographic transactions. In: ECIS 2016 Proceedings.

Belk, R.W., (2014a). Sharing versus pseudo-sharing in web 2.0. Anthropologist, 18, 7- 23. https://doi.org/10.13140/RG.2.1.1630.3842.

Belk, R.W., (2014b). You are what you can access: sharing and collaborative consumption online. Journal of Business Research, 67, 1595-1600. https://doi.org/10.1016/j. jbusres.2013.10.001.

Belk, R.W., Sharing., (2010). Why Not Share Rather than own? Journal of Consumer Research. 36, 715-734. https://doi.org/10.1086/612649.

Belk, R.W., (2007). Annals of American Academy of Political and Social Sciences, 611, 126-140. https://doi.org/10.2307/25097913.

Bellare, M., Namprempre, C., Neven, G., (2009). Security proofs for identity-based identification and signature schemes. Journal of Cryptology, 22, 1-61. https://doi.org/ 10.1007/s00145-008-9028-8.

Benbasat, I., Zmud, R.W., (2003). The identity crisis within the is discipline: defining and communicating the discipline's core properties. MIS Quarterly. 27, 183-194.

Berg, J., Dickhaut, J., McCabe, K., (1995). Trust, reciprocity, and social history. Games and Economic Behavior, 10(1), 122-142.

10.1006/game.1995.1027.

Bogner, A., Chanson, M., Meeuw, A., (2016). A decentralised sharing app running a smart contract on the ethereum blockchain. In: Proceedings of the 6th International Conference on the Internet of Things - loT'16, 177-178. doi:10.1145/2991561.2998465

Böhme, R., Christin, N., Edelman, B., Moore, T., (2015). Bitcoin: economics, technology, and governance. Journal of Economic Perspective, 29, 213-238. https://doi.org/ 10.1257/jep.29.2.213.

Bolton, G.E., Katok, E., Ockenfels, A., (2004). How effective are electronic reputation mechanisms? an experimental investigation. Management Science, 50, 1587-1602. https://doi.org/10.1287/mnsc.1030.0199.

Botsman, R., (2016). We've stopped trusting institutions and started trusting strangers [WWW Document]. TED. URL https://www.ted.com/talks/rachel_botsman_we_ve_stopped_trusting_institutions_and_started_trusting_strangers\#t-715217.

Botsman, R., (2013). The sharing economy lacks a shared definition [WWW Document]. fastcoexist.com. https://www.fastcoexist.com/3022028/the- sharing-economy-lacks-a-shared-definition

Botsman, R., Rogers, R., (2010). What's mine is yours: the rise of collaborative consumption. HarperCollins Publishers. Castelfranchi, C., Falcone, R. Trust Theory: a Socio-Cognitive and Computational Model. 
Cheng, M., (2016). Sharing economy: a review and agenda for future research. International Journal of Hospitality Management. 57, 60-70. https://doi.org/10.1016/j.ijhm.2016.06.003.

Chica, M., Chiong, R., Adam, M.T.P., Damas, S., Teubner, T., (2017). An evolutionary trust game for the sharing economy. IEEE Congress, Evolutionary Computing (CEC) - Proc. 2510-2517. doi:10.1109/CEC.2017.7969610

Christopher, C. M., (2019). The bridging model: exploring the roles of trust and enforcement in banking, bitcoin, and the blockchain. Nevada Law Journal, 17, 139-151.

Cocco, L., Pinna, A., Marchesi, M., (2017). Banking on blockchain: costs savings thanks to the blockchain. Future Internet, 25(9); doi:10.3390/fi9030025, www.mdpi.com/journal/futureinternetFuture Internet.

Connolly, A.J., Kick, A., (2015). What differentiates early organization adopters of bitcoin from non-adopters? In: AMCIS 2015 Proceedings. 1-6. doi:10.13140/RG.2.1.4730.8645

Davidson, S., De Filippi, P., Potts, J., (2016). Economics of blockchain. Social Sciences Research Network, 1-23. https://doi.org/10.2139/ssrn.2744751.

Dan, B., (2015). Blockchain manoeuvres: applying bitcoin's technology to banking. The Banker, May 15, https://www.thebanker.com/TransactionsTechnology/Technology/Blockchain-manoeuvres-applying-Bitcoin-s-technology-to-banking?ct=true, 25.06 .21

Dinger, J., Hartenstein, H., (2006). Defending the sybil attack in P2P networks: Taxonomy, challenges, and a proposal for self-registration. In: ARES 2006 Proceedings. 756-763. doi:10.1109/ARES.2006.45

Douceur, J.R., (2002). The sybil attack. in: international workshop on peer-to-peer systems. International Workshop on Peer-to-Peer Systems IPTPS 2002: Peer-to-Peer Systems pp 251-260, doi: 10.1016/S0140-6736(07)60784-3.

Dredge, D., Gyimóthy, S., (2015). The collaborative economy and tourism: Critical perspectives, questionable claims and silenced voices. Tourism Recreation Research, 40, 286-302. https://doi.org/10.1080/02508281.2015.1086076.

Gandhi, H., More, R., Patil, N., (2019). A blockchain in banking application, Global Journal for Research Analysis, 8(4), 265-276.

Galyna, A., Iryna, S., (2018). The influence of financial technologies on the global financial system stability. Investment Management and Financial Innovations, 15(4), 229-238, DOI:10.21511/imfi.15(4).2018.19

Gupta, A., Gupta, S., (2018). Blockchain technology: application in Indian banking sector. Delhi Business Review, 19(2), 89-94.

Deng, C., Ravichandran, T., (2017). How consumers perceive trustworthiness of providers in sharing economy: effects of photos and comments on demand at airbnb. In: AMCIS 2017 Proceedings.

Hassani, H., Huang, X., Silva, E., (2018). Banking with blockchained big data. Journal of Management Analytics, 5(4), $256-275$.

Hayati, Y., Mai, F. M., Badrul, M., Zulnurhaini, Z., (2018). Behavioral intention to adopt blockchain technology: viewpoint of the banking institutions in Malaysia. International Journal of Advanced Scientific Research and Management, 3(10), 368-377.

Ittay, E., (2017). Blockchain technology: transforming libertarian cryptocurrency dreams to finance and banking realities, The IEEE Computer Society,50(9), DOI: 10.1109/MC.2017.3571042

Chan, S., Chu, J., Nadarajah, S., Osterrieder, J., (2017). A Statistical Analysis of Cryptocurrencies. Journal of Risk Finance and Management, 10, $12-$ 23. https://doi.org/10.3390/jrfm10020012.

Meenakshi, K., George, A. R. et. al., (2018). Green banking through blockchain. International Journal of Research and Analytical Reviews, 1 (12). 212-220.

Liang, L.J., Choi, H.C., Joppe, M., (2018). Exploring the relationship between satisfaction, trust and switching intention, repurchase intention in the context of Airbnb. International Journal of Hospitality Management, 69, 41-48. https://doi.org/10.1016/j. ijhm.2017.10.015.

Litos, O.S.T., Zindros, D., (2017). Trust is risk: a decentralized financial trust platform. In: Kiayias, A. (Ed.), Financial Cryptography and Data Security. Springer International Publishing, Cham, 340-356.

Lu, Y., Zhao, L., Wang, B., (2010). From virtual community members to C2C e- commerce buyers: Trust in virtual communities and its effect on consumers' purchase intention. Electronic Commercial Research Applications, 9, 346-360. https://doi.org/ 10.1016/j.elerap.2009.07.003.

Ma, S., Guo, C., et. al., (2018). Nudging data privacy management of open banking based on blockchain. International Symposium on Pervasive Systems, Algorithms and Networks (I-SPAN), Project:Blockchain technologies and applications, October 2018, DOI: 10.1109/I-SPAN.2018.00021

Mohite, V., (2018). Reducing uncertainty in trade and deciphering future challenges in banking industry through application of blockchain technology. International Bulletin of Management and Economics, 9, special issue, 49-55. 
N. Popova, N. G. Butakova, (2019). Research of a possibility of using blockchain technology without tokens to protect banking transactions Computer Science 2019 IEEE Conference of Russian Young Researchers in Electrical and Electronic Engineering (EIConRus), DOI:10.1109/EICONRUS.2019.8657279

Notheisen, B., Cholewa, J.B., Shanmugam, A.P., (2017a). Trading real-world assets on blockchain. Business Information Systems Engineering, 59, 425-440. https://doi.org/10.1007/s12599-017-0499-8.

Notheisen, B., Hawlitschek, F., Weinhardt, C., (2017b). Breaking down the blockchain hype - towards a blockchain market engineering approach. In: ECIS 2017 Proceedings.

Nunes, M., Correia, J., (2013). Improving trust using online credibility sources and social network quality in P2P marketplaces. Information Systems Technology (CISTI), 8th Iber. Conf. 1-4.

Oh, J.S., Shong, I., (2017). A case study on business model innovations using blockchain: focusing on financial institutions. Asia Pacific Journal of Innovation and Entrepreneurship, 11(3), 335-344.

Rega, F. G., Riccardi, N., (2018). Blockchain in the banking industry: an Overview, White Paper, https://www.researchgate.net/profile/FedericoRega/publication/327601993 Blockchain in the banking industry an Overview/links/5bfefaeaa6fdcc1b8d49f252/Blockchain-in-the-bankingindustry-an-Overview.pdf

Seretakis, A., (2017). Blockchain, securities markets and central banking. Journal of Financial Economics, 1, 425-435. DOI: 10.2139/ssrn.3007402

Sven, M. D., (2018). How blockchain affects business models in international banking. 11th IBA Bachelor Thesis Conference, July 10th, Enschede, The Netherlands.

Ye, G., Chen, L., Ye G., (2016), Blockchain application and outlook in the banking industry, Financial innovation, 2:24, Springer, Heidelberg, 2(24), 1-12, http://dx.doi.org/10.1186/s40854-016-0034-9.

Yeoh, P., (2017). Regulatory issues in blockchain technology. Journal of Financial Regulation and Compliance, 25(2), 61-69.

Yuriy, P., Liudmyla, K., (2018). The opportunities of engaging fintech companies into the system of cross- border money transfers in Ukraine. Investment Management and Financial Innovations, 15(4), 332-344, DOI:10.21511/imfi.15(4).2018.27

\section{Appendix A}

\begin{tabular}{|c|l|l|l|}
\hline Study & Author & Journal & Year \\
\hline S1 & Abhishek Gupta, Stuti Gupta & Delhi Business Review & 2018 \\
\hline S2 & Ye Guo and Chen Liang, Ye Guo and Chen Liang & Financial Innovation (2016) 2:24, Springer & 2016 \\
\hline S3 & Dan Barnes & The Banker & 2015 \\
\hline S4 & Sven Magnus Degener & 11th IBA Bachelor Thesis Conference, Enschede, Netherlands & 2018 \\
\hline S5 & Ittay Eyal & THE I EEE COMPUTER SOCI E TY: COVER & 2017 \\
\hline S6 & Hassani, Hossein, Huang, Xu, Silva, Emmanuel & Journal of Management Analytics & 2018 \\
\hline S7 & David Bates and Paul Migliore & Journal of Securities Operations \& Custody & 2018 \\
\hline S8 & Albekov Adam Umarovich, Vovchenko Natalia & European Research Studies Journal & 2017 \\
\hline S9 & Galyna Azarenkova Iryna Shkodina & Investment Management and Financial Innovations \\
\hline S10 & Yuriy Petrushenko Liudmyla Kozarezenko & Investment Management and Financial Innovations \\
\hline S11 & Luisanna Cocco, Andrea Pinna, Michele Marchesi & Future Internet & 2018 \\
\hline S12 & Catherine Martin Christopher & HeinOnline & 2018 \\
\hline S13 & Harsha Gandhi, Rupali More, Nainisha Patil & GLOBAL JOURNAL FOR RESEARCH ANALYSIS \\
\hline S14 & Hayati Yusof1, Mai Farhana Mior Badrul Munir, & Journal of Advanced Scientific Research and Management \\
\hline S15 & Zulnurhaini Zolkaply & & 2017 \\
\hline S16 & Natalia A. Popova, Natalia G. Butakova & International Journal of Research and Analytical Reviews \\
\hline S17 & Vikram Mohite & IEEE & 2019 \\
\hline S18 & ALEXANDROS SERETAKIS & International Bulletin of Management and Economics \\
\hline S19 & Shenglan Ma1, Chaonian Guo & JOURNAL OF FINANCIAL ECONOMICS & 2018 \\
\hline S20 & Federico Giovanni Rega, Nunzia Riccardi & International Symposium on Pervasive Systems, Algorithms and & 2018 \\
\hline S21 & JaeShup Oh, Ilho Shong & Networks & 2019 \\
\hline S22 & Peter Yeoh & White Paper & 2018 \\
\hline
\end{tabular}

